\title{
Sandstone petrography and provenance of the Chubut Group (Cretaceous) in the Cañadón Matasiete (Golfo San Jorge Basin, central Patagonia): Implications for basin evolution and alluvial organization
}

\author{
Sabrina Ximena Olazábal ${ }^{\mathrm{a}, *}$, Maisa Andrea Tunik ${ }^{\mathrm{b}, \mathrm{c}}$, José Matildo Paredes ${ }^{\mathrm{a}}$ \\ ${ }^{a}$ Departamento de Geología, FCNyCS, Universidad Nacional de la Patagonia San Juan Bosco, Ruta Provincial N 1 S/N, Km 4, 9005 , Comodoro Rivadavia, Chubut, \\ Argentina \\ ${ }^{\mathrm{b}}$ Universidad Nacional de Río Negro. Instituto de Investigaciones en Paleobiología y Geología. Río Negro. Argentina \\ ${ }^{\mathrm{c}}$ Consejo Nacional de Investigaciones Científicas y Técnicas (CONICET). Instituto de Investigaciones en Paleobiología y Geología. Río Negro. Argentina
}

\section{A R T I C L E I N F O}

\section{Keywords:}

Petrography

Provenance

Multiple source areas

Chubut Group

Cretaceous

Golfo San Jorge Basin

\begin{abstract}
A B S T R A C T
Sandstone petrographic data have been used to investigate the provenance of the Matasiete, Pozo D-129, and Castillo formations (Chubut Group) in the Cañadón Matasiete, San Bernardo Fold Belt at Golfo San Jorge Basin, Argentina. Available petrographical data provides evidence of several distinctive volcanic source areas, with minor contributions of metamorphic, plutonic, or sedimentary components. Paleo-volcanic contributions from basic-intermediate (lathwork and microlithic textures) and acidic compositions (felsitic, seriate, granular, and vitric textures) were mainly derived from the Middle-Upper Jurassic rocks of the Lonco Trapial Formation. Pyroclastic components (glass shards, pumice fragments, and eutaxitic textures) derived from coeval volcanic activity in the Andes Cordillera, generated either gradual or abrupt changes in the source of the lithic fragments along the study succession. The observed trends in detrital lithic provenance can be integrated with previous sedimentological and architectural studies of the Matasiete and Castillo formations, revealing that narrow-sheet geometries of the channel fill characterize stratigraphic intervals dominated by pyroclastic components, whereas stratigraphic intervals that contain a low content of pyroclastic materials in the channel fill show ribbon-shaped geometries. Sandstone petrography in volcaniclastic basins can be used to complement other indicators of the evolution of the fluvial systems, providing reliable information about the nature of the changes in the sediment supply within the drainage catchment.
\end{abstract}

\section{Introduction}

Detrital modes of sandstone suites reveal the lithological composition of source terranes and the tectonostratigraphic level reached by erosion in space and time. It brings reliable data to understanding the paleogeography and geological evolution of sedimentary basins, both at regional and local scale (Critelli and Ingersoll, 1995; Critelli et al., 1997; Blair, 1999; Zimmermann and Bahlburg, 2003, Romans et al., 2010; Garzanti, 2016; Limarino and Giordano, 2016; Limarino et al., 2017, among others). One of the fundamental tools for provenance analysis is the determination of the composition of detrital constituents of the sedimentary rocks (Dickinson, 1970; Zuffa, 1985), which in turn is the result of source to sink variables, as upstream lithology, tectonics, climate, distance to source and transport mechanisms (Basu, 1985; McBride and Picard, 1987; Garzanti et al., 2015; Di Capua and Groppelli, 2016) and diagenetic conditions (McBride, 1985).
The fluvial-lacustrine successions of the Chubut Group (Cretaceous) in the Golfo San Jorge Basin (central Patagonia) filled an endorheic basin whose subsurface distribution excesses $150.000 \mathrm{~km}^{2}$ (Figari et al., 1999). It contains the main source rock and hydrocarbon reservoirs of the basin (Jalfin et al., 1999; Homovc and Lucero, 2002), currently providing up to $48 \%$ of the liquid hydrocarbons of the country (Secretaría de Energía, 2017). The basal units of the Chubut Group consist of fluvial deposits included within the Matasiete Formation (Lesta and Ferello, 1972; Sciutto, 1981), currently outcropped along the San Bernardo Fold Belt, and extensive lacustrine deposits that belong to the Pozo D-129 Formation (Lesta, 1968). The fluvial succession of the Castillo Formation (Lesta and Ferello, 1972; Paredes et al., 2015) covers both units. Several outcrop-based studies have focused on the evolution of both the Matasiete and Pozo D-129 formations within the San Bernardo Fold Belt, analyzing their sedimentology and fluvial architecture (Galeazzi, 1989; Paredes et al., 2003, 2007, 2014). Allard et al. (2013,

\footnotetext{
* Corresponding author.

E-mail address: sabrina.olazabal@hotmail.com (S.X. Olazábal).
} 

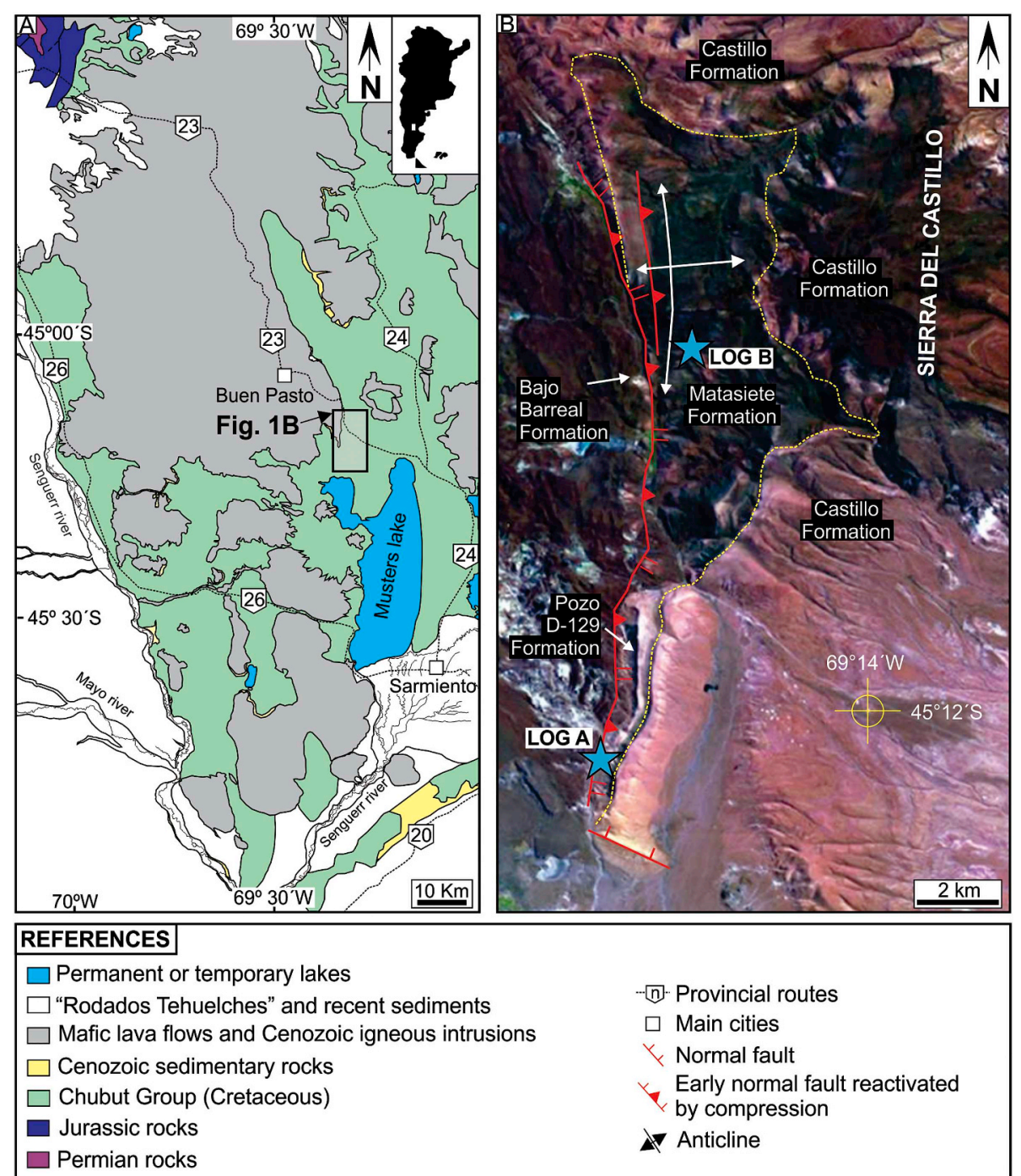

(n). Provincial routes

$\square$ Main cities

$\Varangle$ Normal fault

Early normal fault reactivated

by compression

Anticline

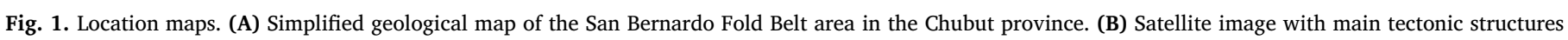

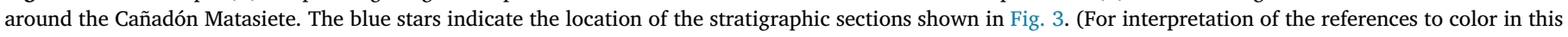
figure legend, the reader is referred to the Web version of this article.)

2015) interpreted that the fluvial deposits of the Matasiete Formation can be considered an exotic fluvial succession (sensu Tooth, 2000; Ori et al., 2007) owing to their physical connection with upland fluvial sedimentary deposits of the Los Adobes Formation in the Cañadón Asfalto Basin, providing a novel paleo-geomorphic scenario with sedimentary corridors connecting both basins (Allard et al., 2017; Figari and García, 2018).

Outcrop-based provenance studies in the Chubut Group have provided detailed characterizations of both the Castillo Formation (Tunik et al., 2004, 2015) and Bajo Barreal Formation (Umazano et al., 2009) source areas. However, although there is a robust geological framework for the Matasiete-Pozo D-129 depositional system, there are relatively scarce data on the sedimentary provenance of both units (exception include Tunik et al., 2004). In order to increase the geological knowledge of the depositional system, and unravel the behavior of positive areas surrounding the Golfo San Jorge Basin during the Aptian, we analyze the detrital sandstone petrography of the basal units of the Chubut Group (Matasiete, Pozo D-129 and Castillo formations) in the Cañadón Matasiete-Sierra del Castillo area located in the San Bernardo Fold Belt (Fig. 1). The aims of the present research are: (i) to characterize the detrital modes of the Matasiete, Pozo D-129 and Castillo formations by analyzing 42 samples along a $750 \mathrm{~m}$-thick section preserved in the Cañadón Matasiete, (ii) to decipher potential source areas of the detrital components, (iii) to discuss the findings with previous sedimentological and architectural studies in an integrated geological framework.

The results of this contribution are of interest to geoscientists working in volcaniclastic settings, both in academic and industrial environments.

\section{Geological framework}

\subsection{Cretaceous structural scenario}

In an overall extensional scenario linked to the break-up of Gondwana and subsequent spreading of the Atlantic Ocean, since early Cretaceous a westward drift of South America occurred (Urien et al., 1995; Granot and Dyment, 2015), leading to the early stages of uplift of the Andes Cordillera (Folguera and Iannizzotto, 2004; Folguera et al., 2011). The Golfo San Jorge Basin in central Patagonia formed as a response to those extensional drivers, overlying a volcanic-volcaniclastic succession of middle Jurassic age. In its southern margin, the volcaniclastic succession is referred either as the Bahía Laura Group (Lesta and Ferello, 1972) or Bahía Laura Volcanic Complex (Sruoga et al., 2008), whereas in its northern counterpart is known as and the Lonco Trapial Group (Lesta and Ferello, 1972) or Marifil Complex (Cortés, 1981). A 
phase of active stretching occurred along several NW-SE, NE-SW and W-E striking half grabens conforming the "Neocomian Basin" (Fitzgerald et al., 1990; Figari et al., 1996; Sylwan, 2001; Paredes et al., 2013; Giampaoli, 2015), which in most cases represent the reactivation of inherited weaknesses in a basement of presumably upper Paleozoic age (Paredes et al., 2018) with ages ranging from Kimmeridgian? to Hauterivian (Seiler and Viña, (1997) in Sylwan et al., 2011; Perez Loinaze et al., 2019). The overlying "Chubutian Basin" records several extensional phases (Figari et al., 1999; Paredes et al., 2013, 2018), and gradual thickness distribution at a regional scale (Fitzgerald et al., 1990) but locally compressional features have been identified (Navarrete et al., 2016). Although historically considered a fold belt mainly developed during the Tertiary, and with the main uplift event in the Miocene (Homovc et al., 1995; Chelotti, 1997; Rodriguez and Littke, 2001), the age of the initial stages of uplifting of the San Bernardo Fold Belt is variable along the fold belt, been considered as old as Albian (Gianni et al., 2015a,b), Upper Cretaceous (Barcat et al., 1989; Allard et al., 2015) or Paleogene (Paredes et al., 2006). Despite these differences, there is a general agreement that the deposition of the lower units of the Chubut Group (e.g., Matasiete and Pozo D-129 formations) occurred in an extensional scenario.

\subsection{Stratigraphy of the Chubut Group}

The Chubut Group (Lesta and Ferello, 1972) at the San Bernardo Fold Belt is a volcaniclastic succession up to $2500 \mathrm{~m}$ of thickness currently integrated by six formations of continental origin (Fig. 2). The volcaniclastic participation is mainly associated with the reworking of ash particles by air and river currents, with minor deposits associated with ash-fall events (Paredes et al., 2007; Umazano et al., 2008, 2012). The beginning of the sedimentation of the Chubut Group occurred in a wide lake (Pozo D-129 Formation) sourced from the north by a drainage catchment whose deposits are part of the Matasiete Formation (Sciutto, 1981; Galeazzi, 1989) and the Los Adobes Formation (Codignotto et al., 1978; Allard et al., 2015). The micropaleontological content of the Pozo D-129 Formation supports a Barremian? -Aptian age for its deposits (Archangelsky and Seiler, 1980; Cortiñas and Arbe, 1981; Laffitte and Villar, 1982; Archangelsky et al., 1984; Hechem et al., 1987; Vallati, 1996, 2013; Carignano et al., 2017). The fluvial succession of the Matasiete Formation represents the record of perennial rivers with seasonality discharge developed in a semi-arid environment. Alluvial architecture studies recognize the dominance of low-sinuosity rivers, scarce braided rivers, and rare meandering streams (Paredes et al., 2003, 2007). Within the San Bernardo Fold Belt, the overlying Castillo Formation (Albian) consists of fluvial systems containing a volcaniclastic floodplain composed of fine ash, with noticeable spatial and vertical variation in alluvial styles (Paredes et al.,
2015), probably as the result of the occurrence of several coeval drainage catchments of different size and integration. Provenance studies in the Castillo Formation (Tunik et al., 2004, 2015) recognize transitional to dissected arc provenance for the detrital components. The fluvial Bajo Barreal Formation (and subsurface equivalents) contains the most important hydrocarbon reservoirs of the basin (Hechem and Strelkov, 2002) and their outcrops have been the subject of detailed sedimentological, architectural and geochemical studies (Hechem et al., 1990; Rodriguez and Bitschene, 1994; Umazano et al., 2008, 2009; Paredes et al., 2016). The remaining units of the Chubut Group are the Laguna Palacios Formation, characterized by aeolian and minor fluvial deposits, with stacked paleosols (Genise et al., 2007), and the Lago Colhué Huapi Formation (Casal et al., 2015), a Maastrichtian fluvial succession (Vallati et al., 2016) developed on extensive floodplains with reduced volcaniclastic participation.

\subsection{Stratigraphy of the study area}

The study area is a classical locality known as Cañadón Matasiete $\left(45^{\circ} 10^{\prime} \mathrm{S}, 69^{\circ} 17^{\prime} \mathrm{W}\right)$, located approximately $70 \mathrm{~km}$ NNW of Sarmiento, Chubut (Figs. 1B and 3A). Several previous contributions published on the geology of the Cañadón Matasiete (e.g., Galeazzi, 1989; Paredes et al., 2003, 2007), and a summary is presented below. Along the Cañadón Matasiete, there is a sedimentological section up to $650 \mathrm{~m}$ thick assigned to the Matasiete Formation. The thickest succession of the Matasiete Formation is outcropped in the core of a double plunging, $\mathrm{N}-\mathrm{S}$ striking asymmetrical anticline associated with a buried, eastdipping reverse fault located west of the anticline. The fold has a steep west-dipping limb (locally overturned) and a broader, more shallowlyinclined eastern limb. Lesta and Ferello (1972) identified in the type section of the Matasiete Formation three Members (Lower, Middle, and Upper), based on the radio of sandstone bodies to floodplain suites. The Lower Member or "Conglomerádica Basal Section" (sensu Ferello and Tealdi, 1950; Galeazzi, 1989) of the Matasiete Formation is $205 \mathrm{~m}$ thick, with channel belts with ribbon geometries separated by thick floodplain successions. The Middle Member or "Morada Inferior Section" (sensu Ferello and Tealdi, 1950; Galeazzi, 1989) consists of $215 \mathrm{~m}$ thick section dominated by red-colored floodplain accumulations and very shallow water deposits, with few interbedded channel belts and several distinctive volcaniclastic levels toward the top of the Middle Member. Within the study area, and $5 \mathrm{~km}$ southward of the classical section of the Cañadón Matasiete, a $100 \mathrm{~m}$ thick succession attributed to the Pozo D-129 Formation consists of dark grey to green mudstones and volcaniclastic sandstones, being covered by the Upper Member of the Matasiete Formation (Fig. 3B). The grey to green succession can be walked out to the Cañadón Matasiete exposures, where distinctive markers (e.g., volcaniclastic levels containing accretionary lapilli) occur

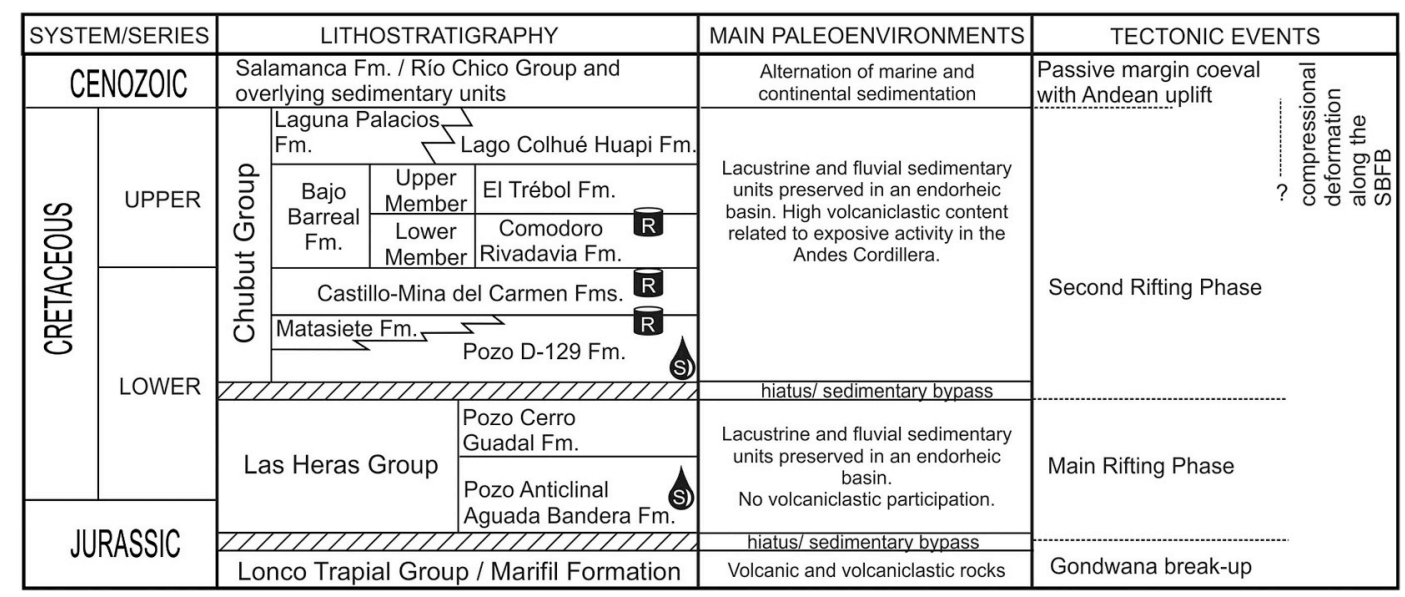

Fig. 2. Chronostratigraphy, paleoenvironments, and main tectonic events during the Cretaceous in the Golfo San Jorge Basin. $S=$ source rock, $R=$ reservoir rock. 


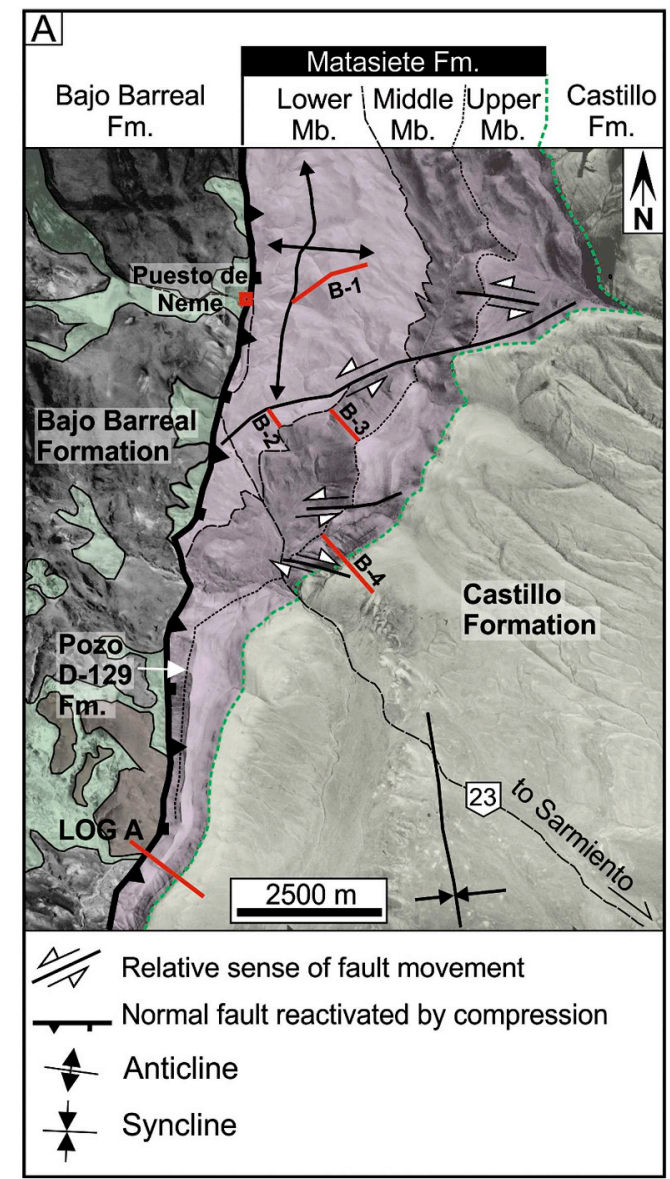

B \begin{tabular}{c} 
LOG A \\
$\begin{array}{c}\text { Península } \\
\text { Baya }\end{array}$ \\
\hline
\end{tabular}$$
\text { N }
$$

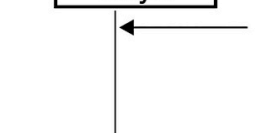

$11 \mathrm{~km}$

LOG B

Cañadón

Matasiete

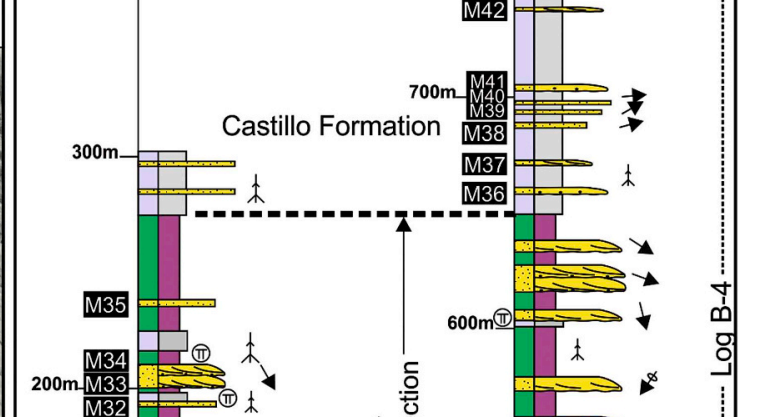

200
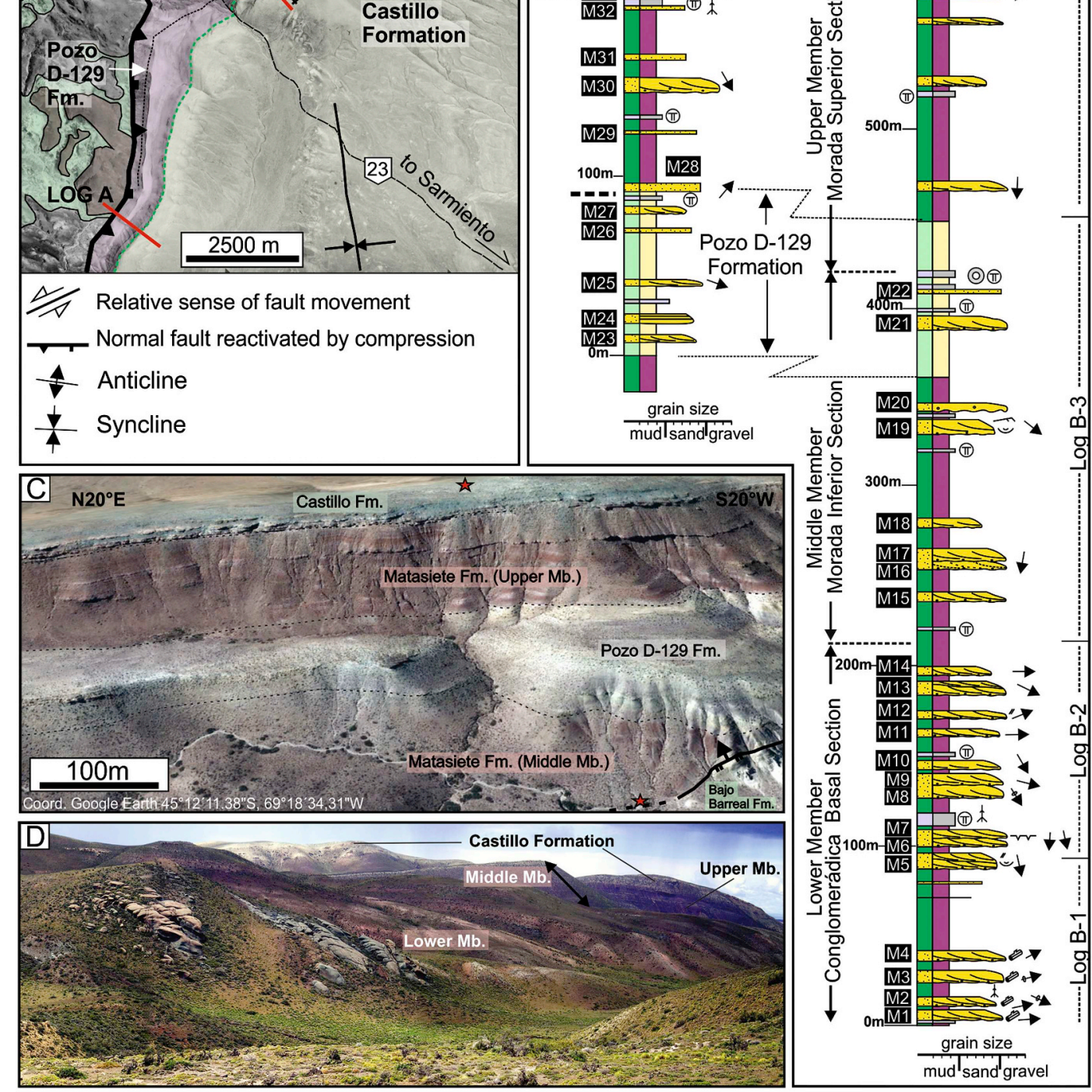

\section{REFERENCES}

\begin{tabular}{|c|c|c|}
\hline dstones & A Roots & Paleocurrents on oriented trunks (main vector) \\
\hline $\mathrm{Ti}$ & () Accretionary lapilli & $\Delta$ Paleocurrents on \\
\hline & vrDesiccation cracks & ction sampled \\
\hline
\end{tabular}

Fig. 3. (A) Detailed location of the sedimentological logs and tectonic features within the Cañadón Matasiete area, with the indication of the boundaries of the Lower, Middle, and Upper Members of the Matasiete Formation. (B) Simplified sedimentological sections of Log A and Log B, with the position of the sandstone samples analyzed in this work. Log B is an integrated section composed of four partial sedimentological sections. (C) Oblique satellite image of Log. A. Red stars indicates the starting and end of the measured section. The pale-grey succession interbedded between the Middle and Upper Member of the Matasiete Formation probably corresponds to the Pozo D-129 Formation. (D) Outcrops of the Lower Member of the Matasiete Formation in the Puesto de Neme location. In the background, there are exposures of the Middle and Upper Member of the Matasiete Formation. At the top of the exposure, there are green-colored deposits that belong to the overlying Castillo Formation. (For interpretation of the references to color in this figure legend, the reader is referred to the Web version of this article.) 
in the uppermost part of the Middle Member and lowermost part of the Upper Member of the Matasiete Formation. The Upper Member or "Morada Superior Section" (sensu Ferello and Tealdi, 1950; Galeazzi, 1989) of the Matasiete Formation is up to 230 m thick, characterized by reddish floodplain fine-grained deposits with vertisol development and isolated channel belts of both meandering and low-sinuosity pattern (Paredes et al., 2007). The entire succession is covered by aggradational, tuffaceous strata that belong to the Castillo Formation (Sciutto, 1981; Paredes et al., 2015).

\section{Methodology}

The petrographic characterization of the Matasiete, Pozo D-129, and Castillo formations was carried out by analyzing 42 sandstone samples obtained from two stratigraphic sections: Península Baya (Log A) and Cañadón Matasiete ( $\log$ B, see Fig. 3B). The samples represent the medium to coarse-grained, typically cross-stratified sandstones that characterize the infill of fluvial channels within the Matasiete Formation, and coastal sandstones in the Pozo D-129 Formation. The petrographic analysis consisted of the identification of detrital constituents in the framework, and percentage and type of matrix, cement, and porosity of sandstone samples, analyzing both the textural characterization and the modal composition. We estimated sphericity and roundness by visual comparisons after Powers (1953), and the type of grain contacts following Taylor (1950). All the thin-sections were impregnated with blue epoxy resin before thin-section preparation for the recognition of optical porosity. Porosity was classified according to Boggs (2009) and Ulmer-Scholle et al. (2015).

The modal compositional quantification was made by the GazziDickinson methodology, counting 450-500 grains per sample in a rectangular grid of $1 \mathrm{~mm}$ of spacing. This method minimizes compositional variability due to the influence of grain size (Dickinson, 1970; Zuffa, 1985).

The sandstone modal fraction is shown in Tables 1 and 2 . The types of rock fragments (Li) were recognized using mineralogy of fragments, textures, and fabrics. Thus, igneous, metamorphic (Lm) and sedimentary (Ls) rock fragments were differentiated. The volcanic lithics (Lv)

Table 1

Modal categories of sandstone.

\begin{tabular}{ll}
\hline Code & Modal Component \\
\hline Qm & Monocrystalline quartz \\
Qp & Polycrystalline quartz \\
Qrv & Quartz in volcanic fragment \\
Fk & Alkali feldspar \\
Pl & Plagioclase \\
Lv & Volcanic lithic fragment \\
Lvl & Lv with lathwork texture \\
Lvm & Lv with microlitic texture \\
Lvs & Lv with seriate texture \\
Lvg & Lv with granular texture \\
Lvf & Lv with felsitic texture \\
Lvv & Lv with vitric texture \\
Lpy & Pyroclastic lithic fragment \\
Tz & Glass shard \\
Pu & Pumice fragment \\
Lp & Plutonic lithic fragment \\
La & Undetermined lithic fragment \\
Lm & Metamorphic lithic fragment \\
Ls & Sedimentary lithic fragment \\
Pse & Pseudomatrix \\
Mxtf & Tuffaceous matrix \\
Czeo & Zeolite cement \\
Ccar & Carbonatic cement \\
Carc & Argillaceous cement \\
Cfer & Iron oxides cement \\
Por & Optical porosity \\
Ot & Other mineral \\
Op & Opaque mineral \\
\hline & \\
\hline & \\
\hline
\end{tabular}

Table 2

Summary of the major detrital framework components recalculated as $100 \%$.

\begin{tabular}{|c|c|c|c|c|c|}
\hline Section & Sample & Qt & $\mathrm{Ft}$ & Lt & Total \\
\hline \multirow[t]{7}{*}{ Castillo Formation } & 42 & 3.3 & 32.6 & 64.1 & 100 \\
\hline & 41 & 5.5 & 47.2 & 47.2 & 100 \\
\hline & 40 & 5.5 & 30.0 & 64.5 & 100 \\
\hline & 39 & 8.0 & 31.4 & 60.5 & 100 \\
\hline & 38 & 9.3 & 38.6 & 52.2 & 100 \\
\hline & 37 & 2.9 & 25.8 & 71.3 & 100 \\
\hline & 36 & 12.7 & 37.4 & 49.9 & 100 \\
\hline \multirow[t]{8}{*}{ Upper Member Matasiete Formation } & 35 & 11.3 & 35.1 & 53.5 & 100 \\
\hline & 34 & 7.6 & 34.1 & 58.3 & 100 \\
\hline & 33 & 5.1 & 20.8 & 74.1 & 100 \\
\hline & 32 & 11.0 & 15.7 & 73.3 & 100 \\
\hline & 31 & 9.1 & 34.0 & 56.9 & 100 \\
\hline & 30 & 21.2 & 24.5 & 54.3 & 100 \\
\hline & 29 & 12.0 & 32.6 & 55.4 & 100 \\
\hline & 28 & 4.9 & 30.6 & 64.6 & 100 \\
\hline \multirow[t]{7}{*}{ Pozo D-129 Formation } & 27 & 24.9 & 60.8 & 14.4 & 100 \\
\hline & 26 & 23.9 & 36.7 & 39.4 & 100 \\
\hline & 25 & 29.2 & 40.4 & 30.4 & 100 \\
\hline & 24 & 15.1 & 44.8 & 40.1 & 100 \\
\hline & 23 & 13.0 & 44.4 & 42.6 & 100 \\
\hline & 22 & 2.6 & 12.9 & 84.5 & 100 \\
\hline & 21 & 9.6 & 15.4 & 75.0 & 100 \\
\hline Middle Member & 20 & 5.0 & 21.3 & 73.7 & 100 \\
\hline \multirow[t]{5}{*}{ Matasiete Formation } & 19 & 11.7 & 32.9 & 55.4 & 100 \\
\hline & 18 & 8.3 & 33.5 & 58.2 & 100 \\
\hline & 17 & 12.8 & 37.0 & 50.2 & 100 \\
\hline & 16 & 7.1 & 31.0 & 61.9 & 100 \\
\hline & 15 & 5.8 & 27.7 & 66.4 & 100 \\
\hline Lower Member & 14 & 4.5 & 36.6 & 58.9 & 100 \\
\hline \multirow[t]{13}{*}{ Matasiete Formation } & 13 & 6.2 & 33.0 & 60.8 & 100 \\
\hline & 12 & 3.9 & 23.9 & 72.2 & 100 \\
\hline & 11 & 4.9 & 40.2 & 54.9 & 100 \\
\hline & 10 & 4.7 & 37.8 & 57.5 & 100 \\
\hline & 9 & 6.0 & 24.7 & 69.4 & 100 \\
\hline & 8 & 9.1 & 30.8 & 60.1 & 100 \\
\hline & 7 & 4.0 & 24.4 & 71.6 & 100 \\
\hline & 6 & 7.5 & 33.2 & 59.3 & 100 \\
\hline & 5 & 6.0 & 27.0 & 67.0 & 100 \\
\hline & 4 & 5.2 & 33.2 & 61.6 & 100 \\
\hline & 3 & 6.7 & 27.9 & 65.4 & 100 \\
\hline & 2 & 8.3 & 34.4 & 57.3 & 100 \\
\hline & 1 & 2.2 & 18.5 & 79.2 & 100 \\
\hline
\end{tabular}

were subdivided according to Dickinson (1970) and Ingersoll and Cavazza (1991). Besides, volcanic lithics were differentiated into paleovolcanic and neovolcanic grains. Paleovolcanic grains are considered to be those derived from the disintegration of previous volcanic rocks, while neovolcanic grains are derived from the coeval volcanic activity (Critelli and Ingersoll, 1995). The quartz grains were separated into their monocrystalline (Qm) and polycrystalline (Qp) varieties (Basu et al., 1975). Feldspars (F) were subdivided into alkali feldspars (Fk) and plagioclase (Pl), counting either fresh or altered clast separately.

Quartz, feldspars, and rock fragments ratio were used to classify the sandstones, according to Folk et al. (1970). Besides, diagrams proposed by Dickinson et al. (1983) were used to characterize the provenance sources.

X-ray diffraction (XRD) and scanning electron micrograph (SEM) techniques were used to determine the mineralogy of interstitial pore space among the framework grains. Nine samples were analyzed by XRD (whole-rock and clays) using a Phillips PW1710 diffractometer (UNPSJB). The texture and morphology of interstitial materials of four samples were observed by SEM using a ZEISS Evo MA15 (UNRN), according to the methods of Welton (1984).

\section{Sandstone petrography}

Modal analysis was performed on 42 arenites: fourteen samples from the Lower Member of Matasiete Formation, six samples from 

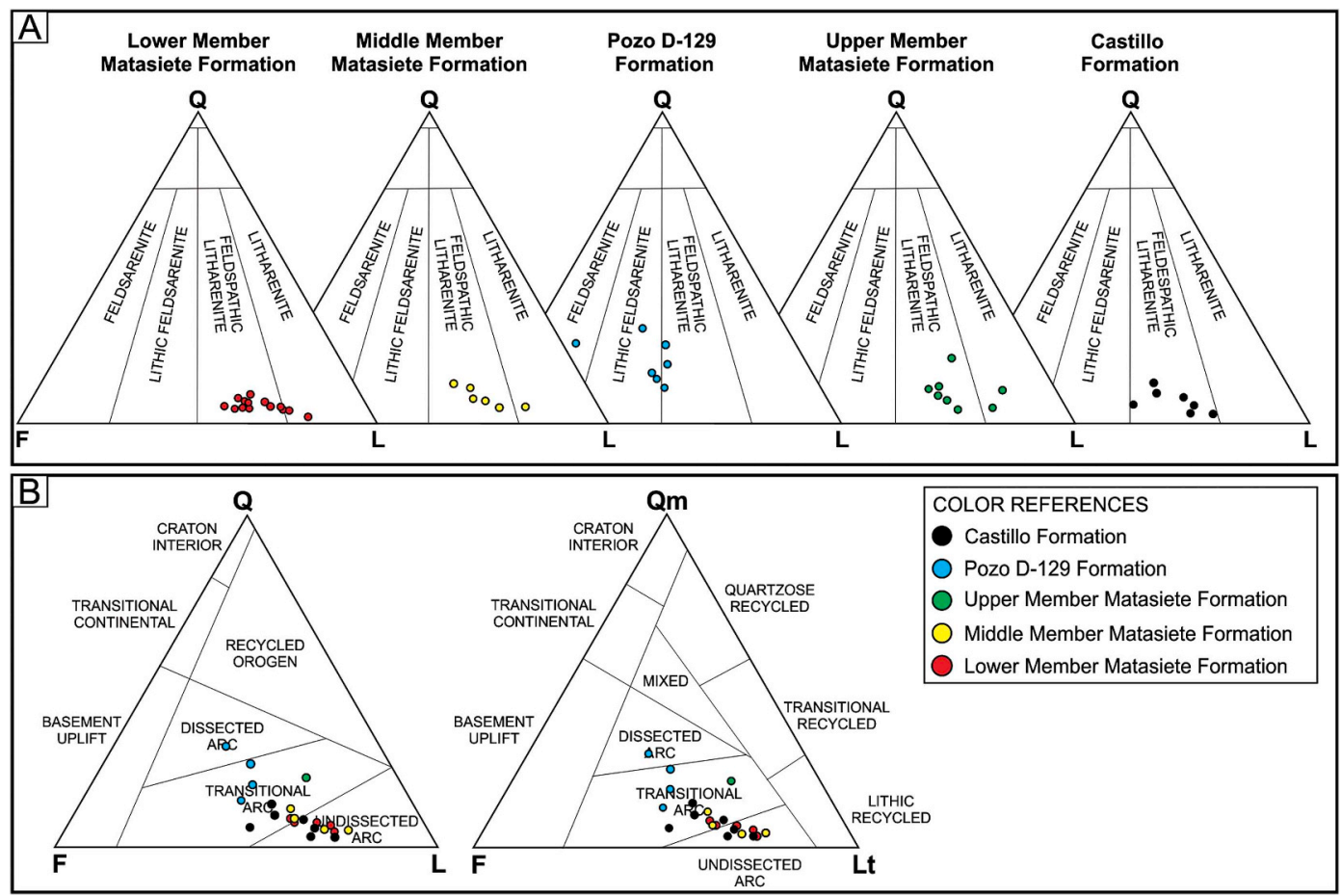

Fig. 4. (A) Ternary plots of $Q$ (total quartz), $F$ (feldspars) and L (lithic fragments) of the Matasiete, Pozo D-129 and Castillo sandstone samples of Logs A and B (Folk et al., 1970). (B) Ternary diagrams of sandstone compositions. The provenance fields are from Dickinson et al. (1983). Qm = Monocrystalline quartz, Lt $=$ Total lithics, $\mathrm{F}=$ Total feldspars.

Middle Member of Matasiete Formation, seven samples from the Pozo D-129 Formation, eight samples from the Upper Member of Matasiete Formation, and seven additional samples from the overlying Castillo Formation. The grain size varies from very coarse $(2 \mathrm{~mm})$ to very fine $(0.062 \mathrm{~mm})$, with most of the samples of medium to coarse-grained size (average $0.5 \mathrm{~mm}$ ). The textures of the sandstones are framework-supported, and they consist of sub-rounded to sub-angular grains with tangential and long contacts and well-to-moderate sorting. A small proportion of pseudomatrix fills the intergranular space, and different types of cement occur, including zeolites (laumontite and analcime), carbonates, and clays (chlorite, mixed-layer chlorite-smectite, and kaolinite). Quartz and feldspar show secondary overgrowths, and iron oxides are scarce.

The sandstones studied are (Fig. 4, Table 3) mainly feldspathic litharenites $(79 \%)$, and a minor proportion of litharenites (12\%), lithic feldsarenites (7\%) and feldsarenites (2\%) sensu Folk et al. (1970). The average modal composition for all analyzed samples is $Q_{9} F_{33} L_{58}$. Compositional modes show low dispersion of values, with negligible variations within the Matasiete Formation, as follows: Lower Member is $\mathrm{Q}_{6} \mathrm{~F}_{30} \mathrm{~L}_{64}$, the Middle Member is $\mathrm{Q}_{8} \mathrm{~F}_{31} \mathrm{~L}_{61}$, and the Upper Member is $\mathrm{Q}_{10} \mathrm{~F}_{29} \mathrm{~L}_{61}$. However, sandstone samples of the Pozo D-129 Formation, interlayered between the Middle and Upper Members of the Matasiete Formation, changes to $\mathrm{Q}_{20} \mathrm{~F}_{44} \mathrm{~L}_{36}$, whereas average modal compositions of samples from the overlying Castillo Formation is $Q_{7} F_{35} L_{58}$.

A total of twenty-one sandstones samples corresponding to Matasiete (10), Pozo D-129 (4), and Castillo (7) formations were used for the interpretation of provenance with ternary diagrams of Dickinson et al. (1983). Select samples have less than $25 \%$ of the intergranular material to avoid modifications in detrital modes due to diagenetic processes. Sandstone studied was likely derived mainly from undissected and transitional arc fields, and minor proportion dissected arc (Fig. 4B). The provenance fields of Dickinson et al. (1983) are commonly used to provenance discrimination and geodynamic setting. However, in the present research, these diagrams do not allow to discriminate between the neovolcanic and paleovolcanic lithic fragments (sensu Critelli and Ingersoll, 1995), being of limited value for understanding the evolution of the study succession.

\section{Mineralogical composition}

\subsection{Quartz}

Quartz comprises from 4 to $14 \%$ (average 6.2\%) of the total rock components (Table 2). Although quartz percentages do not show any significant temporal trend, it increases in the sandstone samples of the Pozo D-129 Formation. Quartz occurs either as monocrystalline grain (Qm) or as polycrystalline grain (Qp). Monocrystalline quartz (Fig. 5A) grains comprise $5.6 \%$ of the total rock components while polycrystalline quartz grains, consisting of five or more sub-grains (Fig. 5B), include less than $0.3 \%$ of the total rock components. Grain sizes vary from $0.2 \mathrm{~mm}$ to $1.0 \mathrm{~mm}$, with sub-rounded to sub-angular shapes. Most of the Qm grains display straight extinction, although some grains show undulose extinction. A few grains have a crystalline shape with embayed volcanic (Fig. 5A) and negative crystals. Occasionally, quartz grains contain minerals like zircon and apatite, and trails of fluid inclusions. These grains exhibit undulatory extinction and either sutured or straight boundaries.

\subsection{Feldspars}

Feldspars (F) are mainly alkali feldspars (orthoclase and sanidine) rather than plagioclase feldspars and comprise from 14.7 to $31.8 \%$ (average $22 \%$ ) of the total rock components (Table 2). In the overall sandstone samples, alkali feldspar (Fk) represents $13.4 \%$ and plagioclase $(\mathrm{Pl}) 8.7 \%$ of the total rock components, with a plagioclase to total feldspars $(\mathrm{Pl} / \mathrm{Ft}$ ) ratio from 0.3 to 0.6 . Both alkali feldspars and plagioclase grains can be fresh, partially replaced to carbonates, kaolinite (Fig. 5C and D), and sericite, or they are entirely altered. Most of the feldspar grains show tabular to sub-angular shapes, with grain sizes varying from $0.5 \mathrm{~mm}$ to $1.2 \mathrm{~mm}$. Felspars commonly show either 
Table 3

Summary of the percentages of the petrography composition of the sandstone studied.

\begin{tabular}{|c|c|c|c|c|c|c|c|c|c|c|c|c|c|c|c|c|c|c|c|c|c|}
\hline Section & Sample & Qm & Qp & Qrv & Fk & $\mathrm{Pl}$ & Lvbi & Lva & Lpy & Lmp & Ls & $\mathrm{La}$ & Czeo & Ccar & Carc & Cfer & Por & Mxtf & Ot & Op & Total \\
\hline Castillo & 42 & 2.2 & 0.0 & 0.2 & 15.6 & 8.9 & 16.9 & 5.8 & 16.0 & 0.0 & 4.4 & 4.9 & 18.2 & 3.3 & 0.0 & 0.0 & 0.7 & 2.4 & 0.2 & 0.2 & 100.0 \\
\hline \multirow[t]{6}{*}{ Formation } & 41 & 3.6 & 0.0 & 0.7 & 22.4 & 13.8 & 10.7 & 7.1 & 15.1 & 0.4 & 0.0 & 2.9 & 4.9 & 3.6 & 10.0 & 0.9 & 3.3 & 0.0 & 0.0 & 0.7 & 100.0 \\
\hline & 40 & 3.3 & 0.2 & 0.4 & 15.1 & 6.9 & 8.0 & 2.7 & 33.6 & 0.2 & 0.0 & 2.9 & 4.4 & 0.0 & 0.0 & 0.0 & 5.1 & 16.7 & 0.0 & 0.4 & 100.0 \\
\hline & 39 & 6.7 & 0.0 & 0.9 & 13.6 & 16.0 & 7.1 & 3.3 & 41.6 & 0.0 & 0.2 & 4.7 & 0.0 & 1.6 & 0.7 & 0.2 & 3.3 & 0.0 & 0.0 & 0.2 & 100.0 \\
\hline & 38 & 8.0 & 0.0 & 0.0 & 15.6 & 17.8 & 11.8 & 3.3 & 26.2 & 1.1 & 0.0 & 2.7 & 0.0 & 1.1 & 9.6 & 0.0 & 2.9 & 0.0 & 0.0 & 0.0 & 100.0 \\
\hline & 37 & 2.9 & 0.0 & 0.0 & 18.0 & 7.3 & 5.6 & 6.2 & 56.4 & 0.0 & 0.0 & 1.8 & 0.0 & 0.0 & 0.0 & 0.0 & 1.1 & 0.0 & 0.7 & 0.0 & 100.0 \\
\hline & 36 & 10.4 & 0.0 & 0.2 & 19.2 & 12.0 & 5.6 & 8.6 & 25.4 & 0.0 & 0.0 & 2.0 & 0.0 & 0.0 & 6.8 & 1.0 & 2.2 & 6.6 & 0.0 & 0.0 & 100.0 \\
\hline Upper Member. & 35 & 6.2 & 0.2 & 0.0 & 10.6 & 9.2 & 7.6 & 7.4 & 8.6 & 1.2 & 0.0 & 5.4 & 8.4 & 0.8 & 17.8 & 3.0 & 9.8 & 0.0 & 0.4 & 3.4 & 100.0 \\
\hline \multirow[t]{7}{*}{ Matasiete Formation } & 34 & 3.5 & 0.2 & 0.6 & 8.1 & 11.4 & 11.6 & 9.3 & 5.8 & 1.0 & 0.0 & 5.6 & 8.1 & 0.2 & 15.1 & 6.2 & 8.1 & 0.0 & 0.2 & 5.2 & 100.0 \\
\hline & 33 & 1.6 & 0.8 & 0.8 & 6.6 & 6.4 & 6.8 & 4.4 & 29.4 & 0.2 & 0.0 & 5.6 & 24.8 & 0.0 & 3.6 & 0.6 & 8.2 & 0.0 & 0.0 & 0.2 & 100.0 \\
\hline & 32 & 5.5 & 0.2 & 0.0 & 3.8 & 4.4 & 9.8 & 9.3 & 16.4 & 0.0 & 0.0 & 2.9 & 14.4 & 0.0 & 18.4 & 0.2 & 14.2 & 0.0 & 0.0 & 0.2 & 99.9 \\
\hline & 31 & 3.2 & 0.0 & 0.4 & 7.6 & 5.8 & 6.6 & 5.4 & 2.6 & 2.2 & 0.0 & 5.6 & 19.6 & 1.0 & 18.4 & 2.8 & 14.6 & 0.0 & 0.2 & 4.0 & 100.0 \\
\hline & 30 & 7.2 & 0.4 & 0.2 & 4.0 & 5.0 & 4.6 & 5.4 & 7.8 & 2.2 & 0.0 & 0.0 & 7.8 & 0.0 & 7.8 & 0.0 & 46.4 & 0.0 & 0.0 & 1.2 & 100.0 \\
\hline & 29 & 5.8 & 0.2 & 0.2 & 6.8 & 10.0 & 11.0 & 7.2 & 6.0 & 1.2 & 0.0 & 3.2 & 21.6 & 1.8 & 2.8 & 0.8 & 20.8 & 0.0 & 0.0 & 0.6 & 100.0 \\
\hline & 28 & 2.0 & 0.0 & 0.8 & 5.0 & 12.6 & 15.2 & 7.8 & 9.0 & 1.0 & 0.0 & 4.2 & 0.0 & 40.2 & 0.0 & 0.0 & 2.2 & 0.0 & 0.0 & 0.0 & 100.0 \\
\hline Pozo D-129 & 27 & 16.7 & 0.0 & 0.6 & 19.2 & 23.2 & 0.4 & 1.3 & 6.9 & 0.0 & 0.0 & 1.5 & 0.0 & 23.4 & 4.6 & 0.0 & 1.5 & 0.0 & 0.4 & 0.2 & 100.0 \\
\hline \multirow[t]{6}{*}{ Formation } & 26 & 15.7 & 0.0 & 0.0 & 13.8 & 10.5 & 1.5 & 5.0 & 14.0 & 0.5 & 0.3 & 4.8 & 0.0 & 0.0 & 14.0 & 9.5 & 10.3 & 0.0 & 0.0 & 0.3 & 100.0 \\
\hline & 25 & 22.4 & 0.7 & 0.2 & 18.7 & 13.6 & 2.2 & 4.0 & 12.7 & 0.0 & 0.2 & 5.1 & 0.4 & 0.0 & 6.7 & 5.6 & 7.6 & 0.0 & 0.0 & 0.0 & 100.0 \\
\hline & 24 & 9.6 & 0.0 & 0.4 & 10.8 & 18.8 & 1.9 & 2.1 & 21.3 & 0.0 & 0.0 & 1.3 & 0.2 & 30.2 & 3.1 & 0.2 & 0.2 & 0.0 & 0.0 & 0.0 & 100.0 \\
\hline & 23 & 10.8 & 0.7 & 0.0 & 23.1 & 16.4 & 2.0 & 6.7 & 25.1 & 0.0 & 1.1 & 3.1 & 0.2 & 0.2 & 2.2 & 2.2 & 5.3 & 0.0 & 0.2 & 0.4 & 99.9 \\
\hline & 22 & 12.6 & 0.8 & 0.2 & 13.4 & 15.4 & 2.4 & 2.4 & 21.8 & 0.0 & 0.0 & 3.4 & 4.2 & 11.6 & 1.2 & 1.0 & 6.2 & 0.0 & 0.0 & 3.4 & 100.0 \\
\hline & 21 & 6.0 & 0.2 & 0.2 & 16.8 & 8.8 & 7.0 & 4.8 & 8.8 & 0.6 & 0.0 & 5.2 & 9 & 18.4 & 3.2 & 0 & 10 & 0.0 & 0.0 & 1.0 & 100.0 \\
\hline Middle Member. Matasiete & 20 & 3.0 & 0.2 & 0.2 & 10.4 & 4.0 & 8.0 & 8.0 & 29.8 & 0.0 & 0.0 & 4.0 & 13.6 & 0.0 & 5.0 & 0.0 & 13.8 & 0.0 & 0.0 & 0.0 & 100.0 \\
\hline \multirow[t]{5}{*}{ Formation } & 19 & 7.0 & 0.4 & 0.2 & 14.8 & 6.6 & 7.2 & 9.8 & 13.8 & 0.8 & 0.0 & 4.4 & 9.6 & 8.2 & 4.8 & 0.0 & 9.6 & 0.0 & 0.0 & 2.8 & 100.0 \\
\hline & 18 & 5.0 & 0.6 & 0.4 & 17.4 & 6.8 & 19 & 9.0 & 9.4 & 0.2 & 0.0 & 4.4 & 0.0 & 8.6 & 2.4 & 0.0 & 13.8 & 0.0 & 0.0 & 3.0 & 100.0 \\
\hline & 17 & 5.8 & 0.4 & 0.4 & 13.0 & 6.0 & 11.8 & 2.8 & 5.4 & 0.4 & 0.0 & 5.4 & 26.2 & 1.4 & 5.0 & 1.4 & 5.6 & 0.0 & 0.6 & 8.4 & 100.0 \\
\hline & 16 & 3.0 & 0.8 & 0.2 & 10.8 & 6.6 & 10.2 & 8.6 & 8.4 & 0.0 & 0.0 & 7.6 & 26.0 & 0.2 & 4.4 & 2.2 & 6.2 & 0.0 & 0.8 & 4.0 & 100.0 \\
\hline & 15 & 2.4 & 0.8 & 0.0 & 11.6 & 3.6 & 15.6 & 4.4 & 10.6 & 0.2 & 0.0 & 5.6 & 8.0 & 11.0 & 1.4 & 1.4 & 19.0 & 0.0 & 0.00 & 4.4 & 100.0 \\
\hline Lower Member. & 14 & 2.8 & 0.0 & 0.2 & 19.4 & 5.0 & 11.2 & 7.0 & 16.8 & 0.4 & 0.0 & 3.8 & 1.4 & 2.4 & 20.0 & 1.4 & 5.4 & 0.0 & 0.2 & 2.6 & 100.0 \\
\hline \multirow[t]{13}{*}{ Matasiete Formation } & 13 & 3.4 & 0.0 & 0.2 & 16.2 & 3.0 & 13.8 & 8.6 & 5.4 & 0.0 & 0.0 & 7.6 & 0.0 & 6.8 & 23.2 & 0.6 & 5.0 & 0.0 & 0.0 & 6.2 & 100.0 \\
\hline & 12 & 2.4 & 0.2 & 0.0 & 10.8 & 5.0 & 24.6 & 12.4 & 4.2 & 0.6 & 0.0 & 6.0 & 6.8 & 17.8 & 0.6 & 2.6 & 5.2 & 0.0 & 0.0 & 0.8 & 100.0 \\
\hline & 11 & 2.0 & 0.4 & 0.4 & 17.6 & 5.4 & 15.4 & 4.8 & 4 & 0.2 & 0.2 & 6.8 & 7.6 & 14.8 & 6.0 & 2.0 & 7.2 & 0.0 & 0.2 & 5.0 & 100.0 \\
\hline & 10 & 3.0 & 0.0 & 0.0 & 19.4 & 4.8 & 18.2 & 8.0 & 5.4 & 0.2 & 0.0 & 5.0 & 1.8 & 3.4 & 21.2 & 1.8 & 4.8 & 0.0 & 0.2 & 2.8 & 100.0 \\
\hline & 9 & 3.2 & 1.0 & 0.2 & 12.2 & 6.0 & 17.2 & 19.0 & 2.4 & 0.4 & 0.0 & 12.2 & 0.0 & 0.4 & 23.8 & 0.4 & 1.2 & 0.0 & 0.00 & 0.4 & 100.0 \\
\hline & 8 & 4.6 & 0.8 & 0.6 & 13.2 & 7.2 & 13.2 & 18.4 & 1.8 & 0.6 & 0.0 & 5.8 & 6.8 & 5.4 & 16.0 & 0.4 & 3.8 & 0.0 & 0.00 & 1.4 & 100.0 \\
\hline & 7 & 2.2 & 0.2 & 0.2 & 11.4 & 4.6 & 12.6 & 12.4 & 13.4 & 0.8 & 0.2 & 7.6 & 2.8 & 0.0 & 16.0 & 0.2 & 12.8 & 0.0 & 0.2 & 2.4 & 100.0 \\
\hline & 6 & 3.8 & 0.4 & 0.8 & 14.4 & 7.8 & 10.6 & 18.0 & 0.2 & 0.6 & 0.8 & 9.4 & 0.0 & 0.2 & 20.8 & 2.8 & 6.4 & 0.0 & 0.6 & 2.4 & 100.0 \\
\hline & 5 & 3.4 & 0.4 & 0.4 & 14.8 & 4.0 & 21.8 & 12.4 & 6.0 & 0.4 & 0.2 & 5.8 & 0.0 & 18.8 & 9.2 & 0.0 & 2.0 & 0.0 & 0.00 & 0.4 & 100.0 \\
\hline & 4 & 1.6 & 0.4 & 0.8 & 13.0 & 5.0 & 17.8 & 5.0 & 1.8 & 0.2 & 0.4 & 8.2 & 17.8 & 5.4 & 8.2 & 0.0 & 2.0 & 0.0 & 2.2 & 10.2 & 100.0 \\
\hline & 3 & 4.0 & 0.0 & 0.6 & 11.4 & 7.8 & 18.4 & 17.4 & 1.4 & 0.4 & 0.2 & 7.2 & 8.8 & 0.0 & 10.2 & 3.0 & 3.8 & 0.0 & 0.8 & 4.6 & 100.0 \\
\hline & 2 & 5.0 & 0.2 & 0.4 & 16.0 & 7.2 & 14.6 & 16.6 & 1.0 & 0.0 & 0.0 & 6.4 & 2.2 & 0.2 & 18.2 & 1.8 & 2.6 & 5.6 & 0.6 & 1.4 & 100.0 \\
\hline & 1 & 1.1 & 0.0 & 0.4 & 7.1 & 5.8 & 35.8 & 8.0 & 0.7 & 2.0 & 0.0 & 8.7 & 0.0 & 0.2 & 25.1 & 2.9 & 0.7 & 0.0 & 0.7 & 0.9 & 100.0 \\
\hline
\end{tabular}

Carlsbad twin, polysynthetic albite, or Carlsbad-albite combined laws, as well as feldspar zonation. The higher feldspar percentage occurs in the Pozo D-129 Formation samples.

\subsection{Rock fragments}

Total lithic fragments comprise from $25.9 \%$ to $49.3 \%$ (average $38 \%$ ) of the total rock components (Table 2), with sizes ranging from $0.5 \mathrm{~mm}$ to $1.6 \mathrm{~mm}$, with sub-rounded to sub-angular shapes. Volcanic rock fragments are dominant, whereas plutonic, metamorphic, and sedimentary rock fragments are scarce (Fig. 6A). We divided the volcanic lithic grains into those derived from basic and intermediate igneous rocks, those derived from acidic sources, and pyroclastic components. Basic and intermediate volcanic rocks show lathwork (Fig. 5D and E) and microlithic (Fig. 5F, G, H) textures, respectively, and constitute from 9.4 to $41.5 \%$ (average $29.1 \%$ ) of the total rock volume (Table 2). Felsitic, seriate (Fig. 5G), granular, and vitric (Fig. 5H) textures are associated with acidic volcanic rocks (Fig. $5 \mathrm{H}$ and I) and constitute from $11.4 \%$ to $28.4 \%$ (average $20.8 \%$ ). Eutaxitic textures, glass shards (Fig. 5J) and pumice fragments (Fig. 5M) together with pseudomatrix (Fig. 5K) indicate the occurrence of pyroclastic rocks (Fig. 5L, N) and comprise from $31 \%$ to $61 \%$ (average $34.4 \%$ ). Metamorphic and plutonic (Fig. $5 \mathrm{O}, \mathrm{P}$ ) rock fragments constitute $\sim 1.5 \%$ of total rock volume, and consist of high-grade metamorphic components and granitic or subvolcanic rock types, respectively. Sedimentary rock fragments are represented by scarce siliciclastic grains (less than 0.5\%). Undetermined lithic fragments (Fig. 5D) occur due to intense alteration, comprising $13.7 \%$ of the total lithic fraction.

Fig. 6 shows the vertical (temporal) changes in the lithic proportion of the studied samples plotted with vertical equidistant distribution and recalculated to $100 \%$ for the total lithic fraction. The percentage of basic and intermediate volcanic lithics decreases gradually through the Lower Member and Middle Member of the Matasiete Formation, and it reduces abruptly in the Pozo D-129 Formation samples. Besides, the percentage of pyroclastic lithics increases in this same sense for the Pozo D-129 Formation.

Sandstone samples from fluvial channels within the Upper Member of the Matasiete Formation display increase in both basic-intermediate and acidic volcanic constituents, with overall reduction of the pyroclastic components (except in a single sample), whereas the Castillo Formation show up to $60 \%$ (average) of lithic fragments, with an abundance of pyroclastic fragments.

In the analyzed samples, the percentage of undetermined lithic fragments lack any significant trend.

\subsection{Accessory framework minerals}

Accessory minerals consist of undetermined opaque minerals, micas (biotite and muscovite), heavy minerals, and, in smaller proportion, organic matter. Opaque mineral grains constitute 3 to $0.1 \%$ and occur 

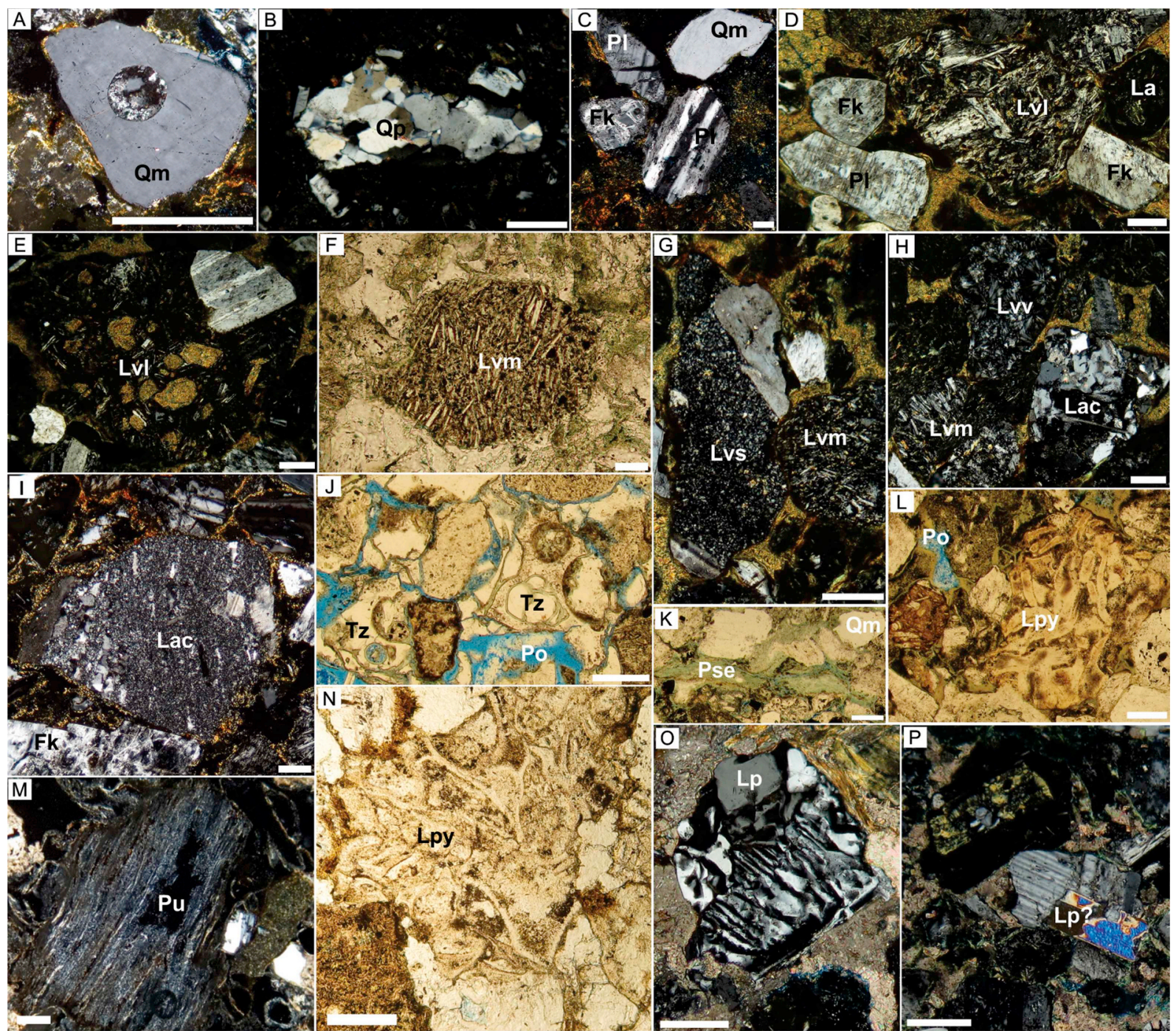

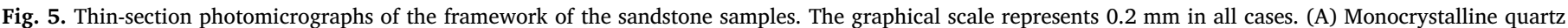

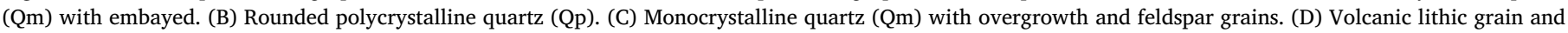

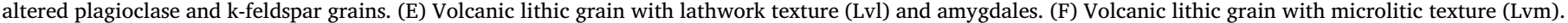

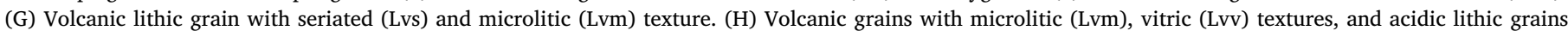

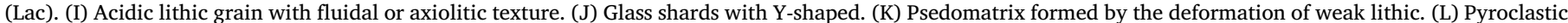

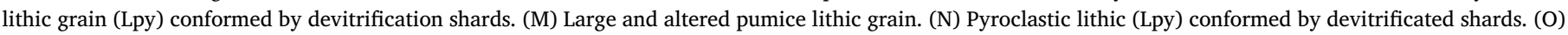
Plutonic lithic (Lp) grain with granophyric texture. (P) Plutonic or metamorphic grain composed of plagioclase and coarse muscovite.

in higher proportion in samples of the Matasiete Formation, commonly oriented parallel to microlaminations. Both varieties of micas are very scarce (less than $0.1 \%$ ) and show flaky habitat, with evidence of deformation and indentation. Besides, micas contain deferrization expansion processes, associated with temperature increase and changes in water chemistry (Ulmer-Scholle et al., 2015). Translucid heavy minerals are zircon, pyroxene, and amphibole grains. Apatite and epidote occur mainly as inclusions. Organic matter is present as intrabasinal detrital components in only two samples of the Lower Member of the Matasiete Formation, and they are oriented parallel to the bedding of the strata. SEM analyses reveal these grains present carbon concentration, and, in thin sections, these grains are brown-colored with multiple fractures.

\subsection{Matrix}

The matrix consists of a tuffaceous matrix and a pseudomatrix. The finer-grained tuffaceous material occurs within the pore space, with percentages ranging from 0.4 to $3.7 \%$ of the total rock volume (Table 2) and shows typical matrix alteration such as authigenic clays and zeolites.

On the other side, the pseudomatrix (sensu Dickinson, 1970) represents $0.9-12.2 \%$ of the total rock volume, being composed of weak, deformed detrital grains with distinctive irregular boundaries (Fig. 5M), probably derived from neovolcanic components (Critelli and Ingersoll, 1995).

\subsection{Cement types and porosity}

Clay minerals, carbonate minerals, silicate minerals (quartz, feldspar, and zeolites) and undetermined iron-manganese oxide minerals are common types of cement of the sandstone (Table 3, Fig. 6).

Zeolite minerals consist of both laumontite and analcime, associated with carbonate cement and clay minerals. Of the 42 analyzed sandstone samples, 20 samples $(47.6 \%)$ record analcime cement, 9 of them contain laumontite $(21.4 \%)$, and the remaining 13 sandstone samples (30.9\%) do not show zeolites as intergranular cement. Laumontite cement occurs as prismatic crystals with two strong cleavages, often 


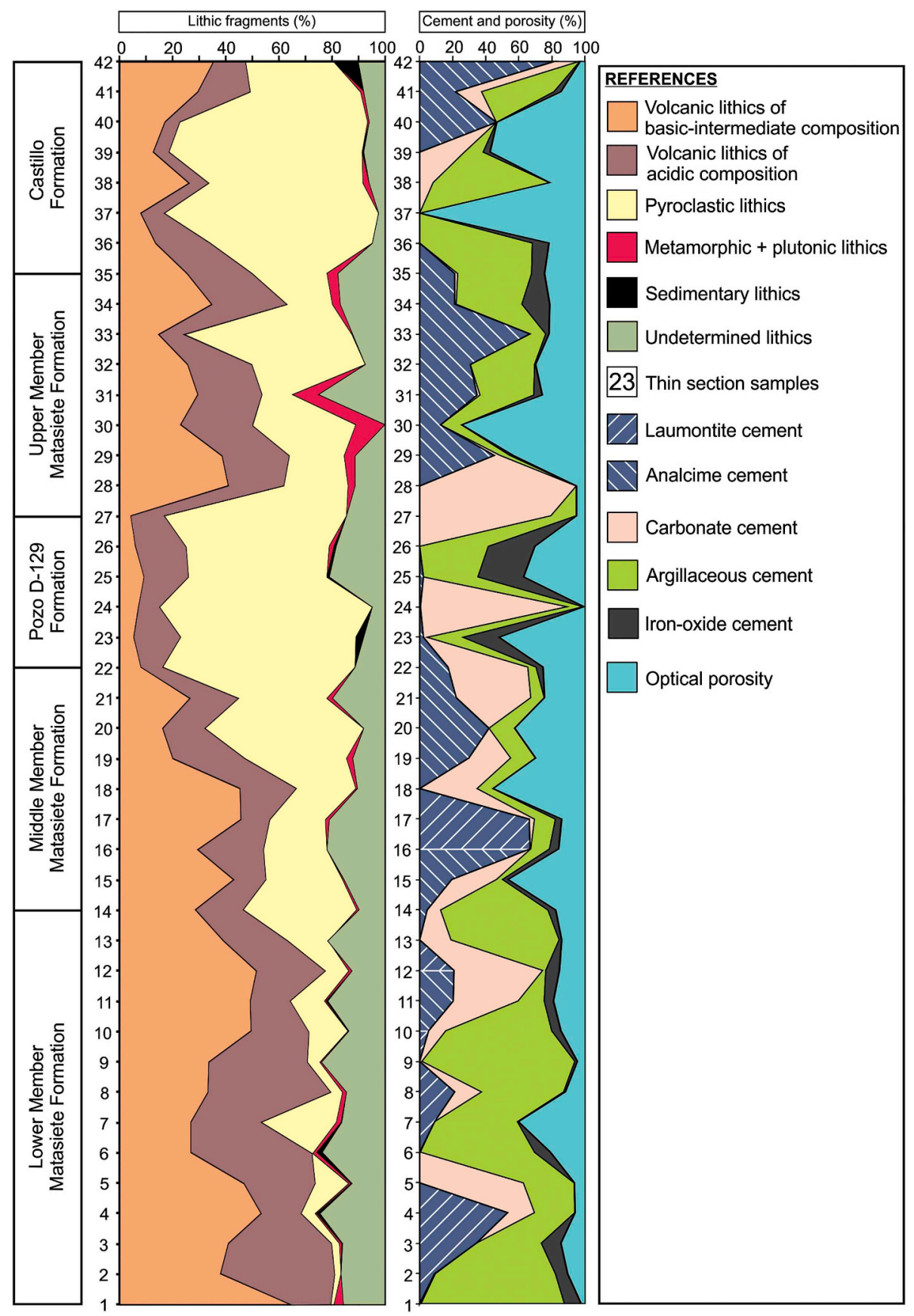

Fig. 6. Vertical trends of lithic components. The sample position indicated left to the figure, is shown in Fig. 3B. Notice the gradual upward increase in pyroclastic lithics in the Lower and Middle Members, and sudden increasing of pyroclastic lithics in both the Pozo D-129 Formation and Castillo Formation, and the corresponding reduction of components derived from basic-intermediate and acidic volcanic sources. The percentage of types of cement and porosity is represented in the right column.

replacing framework grains (Fig. 7A). Blocky pore-filling texture (Fig. 7B) or poikilotopic texture were observed. Analcime cement shows either euhedral trapezohedrons or poikilotopic fill of intergranular pores (Fig. 7C-E), commonly replacing vitric components (Fig. 7H).

Laumontite cement was identified in the Lower Member until $140 \mathrm{~m}$ (sample M12 in Figs. 3B and 6), with alternation of laumontite and analcime in the uppermost Lower Member and basal strata of the Middle Member of the Matasiete Formation (Fig. 6). The remaining of the Middle Member of the Matasiete Formation and overlying units (Pozo D-129 Formation, Upper Member of the Matasiete Formation, and Castillo Formation) only contain analcime cement (Fig. 6).

Quartz cement occurs as euhedral, syntaxial overgrowths around detrital quartz grains (Figs. 5C and 7F) but also occur around feldspar grains (Fig. 7F). The samples that frequently show overgrowths correspond to the sandstones of the Pozo D-129 Formation.

The main argillaceous types of cement are smectite, chlorite, mixedlayer chlorite-smectite, and kaolinite. Smectite occurs as either coating of detrital grains or filling pores, and show highly crenulated forms. Chlorite occurs either as pore-lining authigenic clay minerals below $0.2 \mathrm{~mm}$ around the grains, or show a rosette pattern (Fig. 7L). The presence of mixed-layer chlorite-smectite (Fig. 7I and J) occurs in the samples of the Matasiete Formation. Kaolinite is present as dispersed, well-crystallized aggregates within pore space. Carbonate cement presents a poikilotopic texture (Fig. 7D-H) and, in some cases, it appears as 

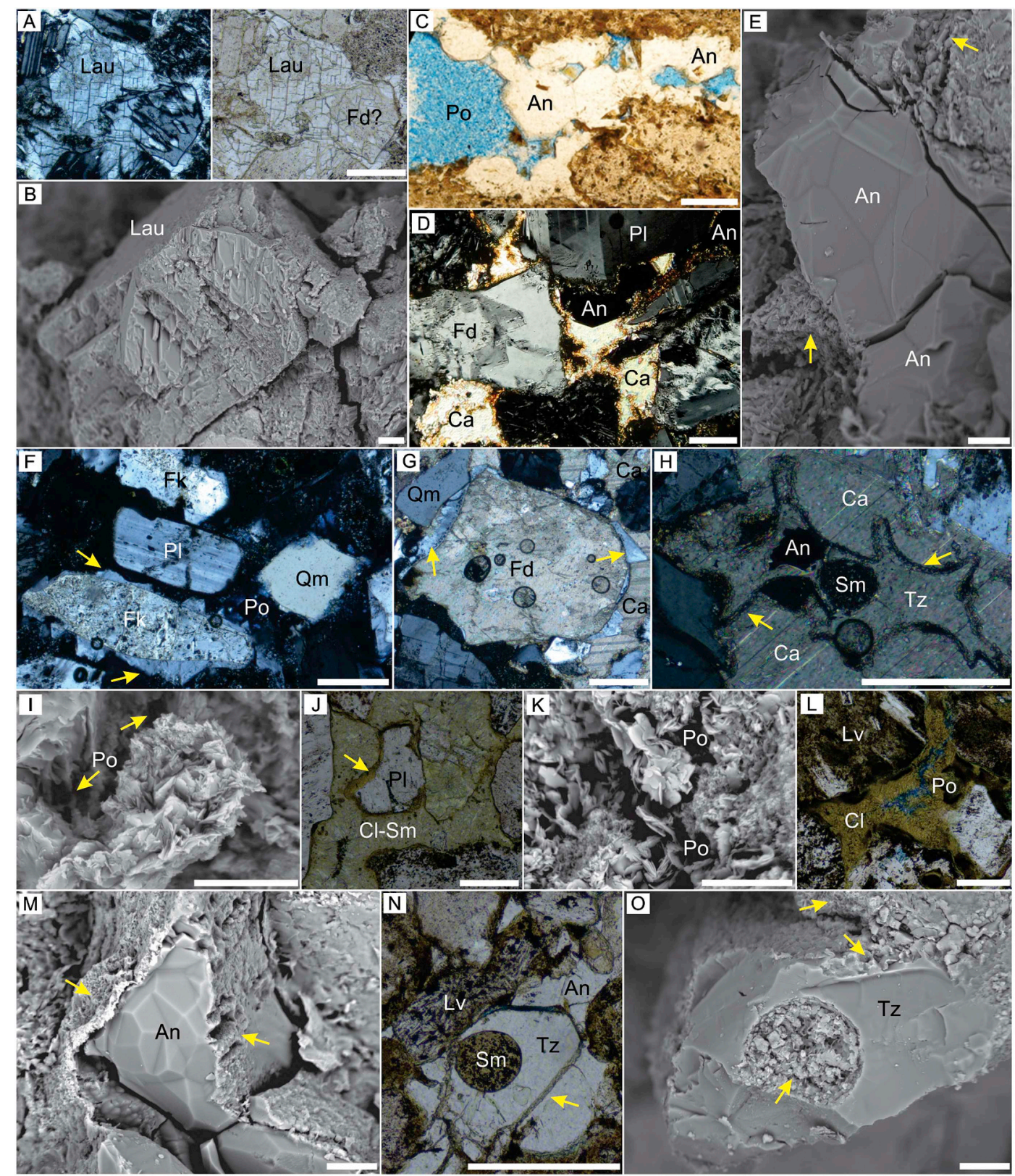

Fig. 7. Photomicrography of the types of cement and replacements of the sandstones. The graphical scale represents $0.2 \mathrm{~mm}$ in the thin sections and $20 \mu \mathrm{m}$ in SEM. (A) Intergranular pore filled by laumontite (Lau) with prominent cleavage, and laumontite replacing a feldspar grain? (Fd?). (B) SEM image of a pore filled with blocky laumontite (Lau) cement. (C) Fracture filled with trapezohedral crystals of analcime (An) and pore space (Po). (D) Intergranular pore filled, notice relationship crystal analcime (An) and poikilotopic carbonate (Ca). (E) SEM image of a pore system filled with trapezohedral crystals of analcime (An) surrounded by clay minerals (yellow arrow). (F) Feldspar grain with euhedral and authigenic overgrowths (yellow arrow). (G) Feldspar grain (Fd) replaced by carbonate. Notice the fresh appearance of the overgrowths (yellow arrow). (H) Cuspate glass shard (Tz) entirely replaced by carbonate (Ca), analcime (An) and smectite (Sm). Notice the coating of pore-lining clays (yellow arrow). (I) SEM image of authigenic, mixed-layer chlorite-smectite. Inter-crystalline porosity (Po) is indicated with arrows. (J) Graincoating of the mixed-layer chlorite-smectite (Cl-Sm) clays. (K) SEM image of authigenic chlorite cement, with intercrystalline porosity (Po). (L) Grain-coating of chlorite $(\mathrm{Cl})$ and associated intercrystalline porosity (Po). (M) SEM image of a glass shard replaced by trapezohedral crystals of analcime (An) coated with clay minerals (yellow arrow). (N-O) Thin-section and SEM image of volcanic glass shards (Tz) with arcuate molds, these are replaced by analcime (An) and have a rim clay (yellow arrow). (For interpretation of the references to color in this figure legend, the reader is referred to the Web version of this article.)

a replacement of detrital grains (Fig. $7 \mathrm{G}$ and $\mathrm{H}$ ). More than $70 \%$ of the samples register carbonatic cement. Iron or manganese oxides occur either as amorphous precipitates filling the pores or as a coating around the detrital grains (Fig. 7L, N).

The optical porosity of the studied sandstones varies from $2.7 \%$ to $15.5 \%$ (average $7.5 \%$ ) of the total rock volume (see Figs. 5 and 7). It is typically of secondary type, recording dissolution processes in minerals grains (quartz, feldspar), lithic grains and cement (Fig. 5J-L). Dissolution processes generate either crystal-moldic or grain-moldic pores with
$0.75 \mathrm{~mm}-0.2 \mathrm{~mm}$ of size, and either partial or total dissolution of cement, ranging from $0.3-0.1 \mathrm{~mm}-0.01 \mathrm{~mm}$ in size (Fig. 7I and $\mathrm{K}, \mathrm{L}$ ). Intercrystalline porosity occurs within cement fills and can reach up to $0.1 \mathrm{~mm}$ in size. Porosity associated with local fractures can show 0.3-0.1 mm in width (Fig. 7C). Both the groundmass and crystals of the volcanic lithic grains show intragranular primary porosity, with pores ranging between 0.4 and $0.2 \mathrm{~mm}$ in size, whereas intercrystalline pores occur subordinately. 


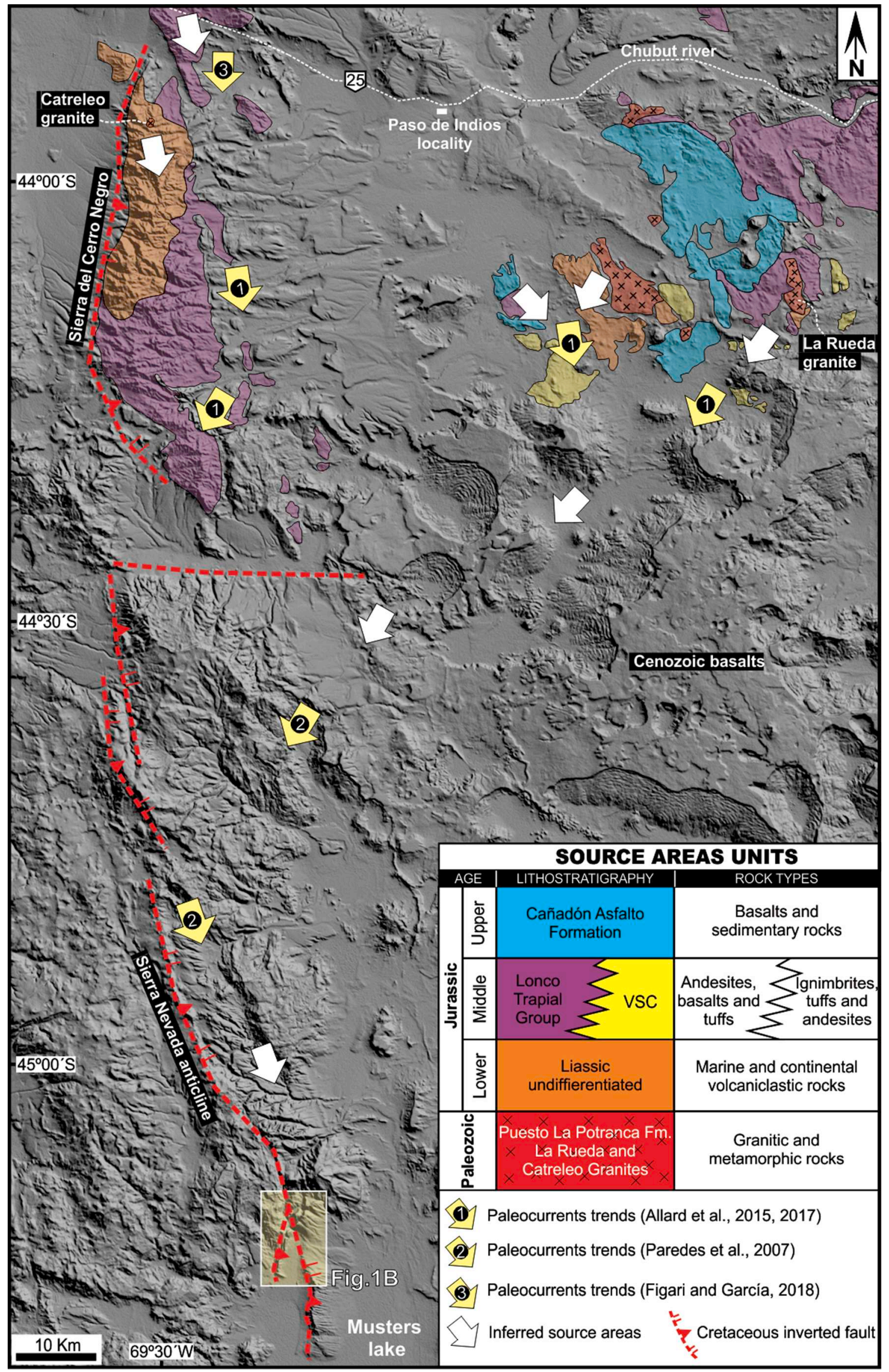

Fig. 8. General map with potential provenance sources areas to sandstones studied. Lithostratigraphic units modified from Robbiano (1971), Anselmi et al. (2004a, b) and Giacosa et al., 2008. VSC: Volcano Sedimentario Complex (sensu Clavijo, 1986). 


\section{Discussion}

Understanding of temporal and spatial changes of detrital composition in continental successions constitutes a fundamental tool to unravel both the organization of positive areas in the headwaters of the drainage catchments, and the impact of allogenic forcing factors as tectonics, climate changes, and coeval volcanic activity (Dickinson and Suczek, 1979; Fisher and Smith, 1991; Critelli and Ingersoll, 1995; Zuffa et al., 1995, 2000). The studied succession constitutes the thickest exposure of the basal units of the Chubut Group along the San Bernardo Fold Belt, being the single exposure of the Lower and Middle Members of the Matasiete Formation (Paredes et al., 2003).

\subsection{Provenance areas}

The lithic composition of sandstones included within the Matasiete, Pozo D-129, and Castillo formations indicates a high proportion of volcanic and volcaniclastic components, whereas plutonic, metamorphic and sedimentary rocks are subordinate. Due to the low amount of quartz and other non-volcanic grains, and the dominance of pyroclastic (neovolcanic) lithic grains, most of the sandstone samples reflect an undissected to transitional arc setting (Dickinson et al., 1983).

Detrital quartz grains were likely derived either from the weathering of both igneous and metamorphic rocks (Basu et al., 1975; Folk, 1980 ) or sedimentary rocks. The monocrystalline grains with crystalline shape and embayments are indicative of extrusive igneous rocks (Basu et al., 1975; Ulmer-Scholle et al., 2015). The polycrystalline quartz grains with either large size of individual or polycrystalline quartz fragments with sutured boundaries may indicate either igneous or high-grade metamorphic sources (Blatt, 1967; Basu et al., 1975). The detrital feldspar grains may be derived from both metamorphic and igneous rocks (Datta, 2005). The values obtained for the plagioclase to total feldspar ratio indicate mixed plutonic and metamorphic sources (Dickinson, 1970). The probable sources of granitic composition are the Upper Paleozoic granites of Sierra Mora and Catreleo, outcropped in small exposures northward of the study area (Robbiano, 1971), whereas crystalline rocks assigned to La Potranca Formation constitute the likely source area of the granitic-metamorphic components (Anselmi et al., $2004 a, b)$. The scarce representativity of both plutonic and metamorphic components in the sandstone samples suggests that such terranes constitute a minor source area. Several volcanic-volcaniclastic units included within the Lonco Trapial Formation (Lesta and Ferello, 1972) and, to a lesser extent, the Las Leoneras Formation (Nakayama, 1973; Figari, 2005) constitute the volcanic basement of the Cañadón Asfalto basin. Basic and intermediate rocks of the Lonco Trapial Formation are the substrate of Cretaceous successions northward of the study area (Anselmi et al., 2004a,b; Silva Nieto et al., 2002; Silva Nieto, 2005), and are the most probable source of the basic-intermediate components in the detrital fraction of the study succession (Zaffarana et al., 2018). The sedimentary components, although very subordinate, can be derived from the Middle-Upper Jurassic Cañadón Asfalto and Cañadón Calcáreo formations (Stipanicic et al., 1968; Proserpio, 1987; Cúneo et al., 2013; Figari et al., 2015).

Our results are slightly different to those obtained from the subsurface of the South Flank of the basin for the Late Cretaceous units (Limarino and Giordano, 2016), where provenance and geochemical data reveal at least three main sources of clasts. In the southern margin of the basin, the main source of particles was derived from fluvial systems transporting a large proportion of volcanic clasts linked to coeval Andean activity, with subordinate supply from the Precambrian basement and Jurassic volcanic units (Limarino and Giordano, 2016; Paredes et al., 2020).

Besides, published paleoflow data from previous studies within the San Bernardo Belt area (Sciutto, 1981; Paredes et al., 2003, 2007) indicate a dominant S-SSE paleotransport direction for the Matasiete Formation. Those data, integrated with paleoflow data from the laterally equivalent Los Adobes Formation in the Cañadón Asfalto Basin (Allard et al., 2015, 2017) reveal that transportation through fluvial systems was, at regional scale, mainly southward, to the lake of the Pozo D-129 Formation. In this scenario, structural highs of Paleozoic and Jurassic rocks, currently exposed northward of the study area (Fig. 8) constituted the likely source of the detrital fragments.

\subsection{Temporal compositional trends and impact on the alluvial architecture}

Upward content of volcanic lithics of both basic-intermediate and acidic compositions decreases gradually in sandstone samples of the Lower and Middle Members of Matasiete Formation (Fig. 6A), with the corresponding increase in pyroclastic lithic fragments. Gradual changes in detrital compositions could indicate unroofing (Dorsey, 1988; Colombo, 1994; Nagel et al., 2014), but our results indicate that the paleo-volcanic components derived from the Lonco Trapial Formation, dominated by basic-intermediate compositions, were gradually changed by pyroclastic components related to coeval volcanic activity. We interpreted the neovolcanic origin of the pyroclastic lithics of the study succession due to the abundance of glass shards and pumice fragments (Fig. 5J, M), components that sharply increase in the Pozo D129 samples to up to $60 \%$ of the total lithic fragments. The fluvial deposits of the Upper Member of the Matasiete Formation overlying lacustrine facies of the Pozo D-129 Formation reflects a renewed increase in both basic-intermediate and acidic volcanic clasts within the detrital fraction, but again in basal levels of the Castillo Formation the pyroclastic components dominate the lithic composition (Tunik et al., 2015) diluting the background signal derived of paleo-volcanic source areas.

Beyond the possible interpretation of the vertical replacement of volcanic components derived from underlying volcanosedimentary units with pyroclastic fragments, the stratigraphic record of the Matasiete and Castillo Formations contain additional information useful to unravel the significance of the volcaniclastic signature, as revealed using petrography of sandstones. According to Paredes et al. (2007) the alluvial architecture of the Matasiete Formation contains ribbon-shaped fluvial channel fills with width-to-thickness ratio of 14, except in pyroclastic-rich intervals located on top of the Middle Member, and in channel belts emplaced directly over thick, finegrained, pyroclastic beds, where multichannel, braided rivers show sheet-shaped geometry with width-to-thickness ratio up to 75-90. Besides, channel fills in the Castillo Formation have a width-to-thickness ratio of 40-45. Those changes in the alluvial architecture and style of the fluvial channels were attributed to combined effect of increased runoff and reduced infiltration capacity of pyroclastic floodplains in relation to soils, that favored the flashiness of the river discharge and development of wider rivers (e.g., Smith, 1991; Umazano et al., 2008; Manville et al., 2009). Moreover, the present research shows that compositional changes in the sand-sized components of the channel fills can be linked to the observed alluvial architecture (i.e., the width to thickness ratio of the channel fill). Log B corresponds to the exact sedimentological section considered the type section of the Matasiete Formation (Paredes et al., 2007: their Fig. 5). The true width of channels and pyroclastic content of the channel fills within the Lower and Middle Member of the Matasiete Formation, and in the overlying Pozo D-129 Formation along Log B are presented in Fig. 9. Sandstone samples of Log B show that the stratigraphic intervals with scarce pyroclastic components contain ribbon-shaped channel fills, whereas the stratigraphic intervals containing a high proportion of pyroclastic components in the channel fill show narrow-sheet geometries (sensu Gibling, 2006).

Besides the alluvial architecture of fluvial successions is controlled by a set of autogenic and allogenic controls (Bridge, 2003; Miall, 2014), contemporaneous volcanism constitutes a significant control of perivolcanic basins (Mathisen and Vondra, 1983; Smith, 1991; Kataoka and Nakajo, 2002; Kataoka et al., 2009). Notably, sudden incorporation of 

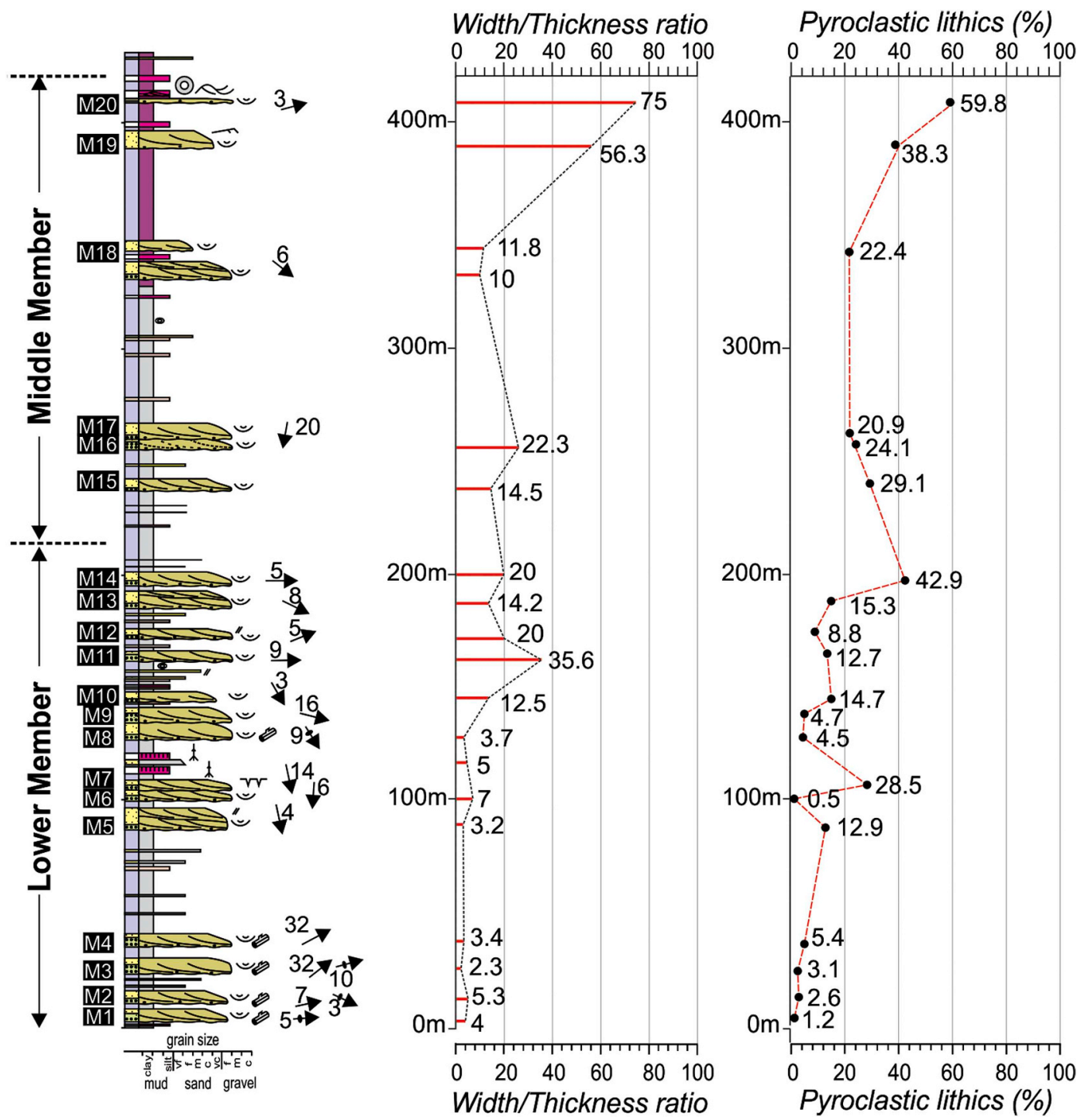

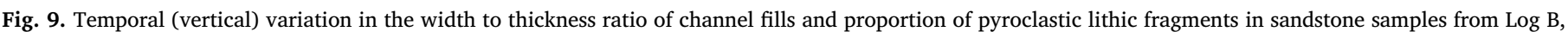

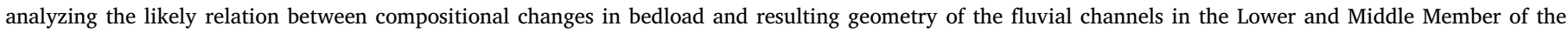

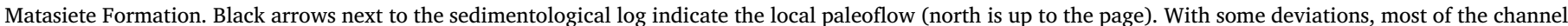

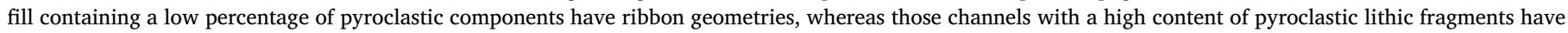
narrow-sheet geometries.

pyroclastic particles within the drainage catchment results in increased sediment supply, changing the composition of both bedload and suspension load (Critelli and Ingersoll, 1995; Umazano et al., 2008; Di Capua and Groppelli, 2016). With increasing volumes of sediment during syn-eruptive stages, both increase in the avulsion frequency and lateral migration rate can occur (Bryant et al., 1995; Mack and Leeder, 1998), favoring the development of wider channels, commonly with braided style (Smith, 1991; Kataoka et al., 2009). Although the precise impact on the fluvial dynamic of the observed detrital framework changes can not be established using petrography solely, the integration of petrographical studies of fluvial successions can complement alluvial architectural studies, by unraveling subtle changes in the nature of the sediment supply.

\section{Conclusions}

The analysis of petrographical data of sandstones of the Matasiete, Pozo D-129, and Castillo Formations (Aptian-Albian) using 42 thin-sections along a $750 \mathrm{~m}$ thick succession in the Cañadón Matasiete (San Bernardo Fold Belt, Golfo San Jorge Basin) yields the following conclusions.
1) The analyzed arenites mainly correspond to feldspathic litharenites, and a minor proportion of litharenites, lithic feldsarenites, and litharenites (Folk et al., 1970). The detrital modes are distributed into the undissected to transitional magmatic-arc, with some samples in the dissected arc field (Dickinson et al., 1983).

2) Detrital modes of sandstones reflect provenance from different volcanic source terranes, with scarce participation of metamorphic, plutonic, or sedimentary constituents. Observed volcanic rock fragment textures suggest volcanic inputs from intermediate to basic products (microlithic and lathwork textures) and acidic source areas (felsitic, seriate, granular, and vitric textures) derived from volcanicvolcaniclastic successions included probably within the Lonco Trapial Formation (Middle-Upper Jurassic).

3) Increases in the pyroclastic constituents such as glass shards and pumice fragments in the sandstone samples are related to the coeval volcanic activity in the Andes Cordillera. Those changes occurred gradually throughout the Lower, Middle, and Upper Members of the Matasiete Formation, with abrupt increasing in pyroclastic participation in the Pozo D-129 and Castillo formations.

4) The dilution of paleo-volcanic components by incorporation of 
neovolcanic lithic fragments in the channel fills impacts on the geometry of the resulting channel fills. Ribbon-shaped channel fills contain a low content of pyroclastic fragments, whereas stratigraphic intervals containing a high content of pyroclastic clasts show channel fills with narrow-sheet geometries.

5) Besides the use of provenance studies to reconstruct the paleogeography of source terranes, in volcaniclastic basins, the methodology is useful to unravel the subtle influence of volcanism on sediment supply within the drainage catchment. Those impacts can be better evaluated through the integration of sedimentological, alluvial architecture, and petrographical studies.

\section{CRediT authorship contribution statement}

Sabrina Ximena Olazábal: Methodology, Formal analysis, Investigation, Writing - original draft, Visualization. Maisa Andrea Tunik: Methodology, Investigation, Writing - review \& editing. José Matildo Paredes: Conceptualization, Formal analysis, Investigation, Resources, Writing - original draft, Visualization, Project administration, Funding acquisition.

\section{Acknowledgments}

We wish to thanks Hugo Neme, owner of the Estancia El Castillo in the Cañadón Matasiete, for its hospitality over the years. We also thank journal reviewers Carlos Oscar Limarino and Patricia Ciccioli for valuable corrections and suggestions that substantially improved the final manuscript. Financial and logistical support was provided through PICT 2012-1369 (ANPCyT), and the Departamento de Geología (FCNyCSUNPSJB), respectively.

\section{Appendix A. Supplementary data}

Supplementary data to this article can be found online at https:// doi.org/10.1016/j.jsames.2019.102463.

\section{References}

Allard, J.O., Paredes, J.M., Foix, N., Giacosa, R.E., 2013. Utilización de análogos modernos para la reconstrucción paleogeográfica del sistema depositacional de las formaciones Los Adobes-Matasiete-Pozo D-129: potential exploratorio de caracterizar las cabeceras fluviales. Primeras Jornadas Geológicas de la Cuenca del Golfo San Jorge, Resúmenes: 19-20. Comodoro Rivadavia.

Allard, J.O., Paredes, J.M., Foix, N., Giacosa, R.E., 2015. Conexión cretácica entre las cuencas del Golfo San Jorge y Cañadón Asfalto (Patagonia): paleogeografía, implicancias tectonoestratigráficas y su potential en la exploración de hidrocarburos. Rev. Asoc. Geol. Argent. 72, 25-41.

Allard, J.O., Foix, N., Clavijo, R., Ferreira, L., Iovine, G., Urrez, N., Sánchez, F., Rodriguez, A., Bueti, S., 2017. Corredores sedimentarios cretácicos (Barremiano-Aptiano) en la cuenca del Golfo San Jorge: Origen, arquitectura e impacto en la exploración de hidrocarburos. In: XX Congreso Geológico Argentino, actas ST1: 7-12. San Miguel de Tucumán.

Anselmi, G., Gamba, M.T., Panza, J.L., 2004a. Hoja Geológica N 4569-IV, Los Altares, Provincia del Chubut. Servicio Geológico Minero Argentino, vol. 313. pp. 98 (Buenos Aires).

Anselmi, G., Panza, J.L., Cortés, J.M., Ragona, D., 2004b. Hoja Geológica N 4569-II, El Sombrero, Provincia del Chubut. Servicio Geológico Minero Argentino, vol. 271. pp. $1-87$.

Archangelsky, S., Seiler, J., 1980. Algunos resultados palinológicos de la perforación UN Oil OS-1 del SO de la Provincia del Chubut, Argentina. In: $2^{\circ}$ Congreso Argentino de Paleontología y Bioestratigrafía, Actas, vol. 5. pp. 215-225 (Buenos Aires).

Archangelsky, S., Baldon, A., Gamerro, J.C., Seller, J., 1984. Palinología estratigráfica del Cretácico de Argentina Austral. III. Distribución de las especies y conclusiones. Ameghiniana 21, 15-33.

Barcat, C., Cortiñas, J.S., Nevistic, V.A., Zucchi, H.E., 1989. Cuenca Golfo san Jorge. In: In: Chebli, G.A., Spalletti, L.A. (Eds.), Cuencas Sedimentarias Argentinas. Serie de Correlación Geológica, vol. 6. San Miguel de Tucumán, pp. 319-345.

Basu, A., 1985. Influence of climate and relief on compositions of sands released at source areas. In: In: Zuffa, G.G. (Ed.), Provenance of Arenites, N.A.T.O. Advanced Study Institute Series, vol. 148 Reidel, Dordrecht 1-1.

Basu, A., Young, S.W., Suttner, L.J., James, W.C., Mack, G.H., 1975. Re-evaluation of the use of undulatory extinction and polycrystallinity in detrital quartz for provenance interpretation. J. Sediment. Petrol. 45, 873-882.

Blair, T., 1999. Cause of dominance by sheetflood vs. debris-flow processes on two adjoining alluvial fans, Death Valley, California. Sedimentology 46, 1015-1028. Blatt, H., 1967. Original characteristics of quartz grains. J. Sediment. Petrol. 37, 401-424. Boggs, S., 2009. Petrology of Sedimentary Rocks, second ed. University of Oregon.

Bridge, J.S., 2003. Rivers and Floodplains: Forms, Processes and Sedimentary Record. Blackwell, pp. 1-491.

Bryant, M., Falk, P., Paola, C., 1995. Experimental study of avulsion frequency and rate of deposition. Geology 23, 365-368.

Carignano, A.P., Paredes, J.M., Olazábal, S.X., Valle, M.N., 2017. Ostracoda (Crustacea) from the Pozo D-129 formation (upper Barremian?Aptian), Golfo san Jorge Basin, Patagonia, Argentina: taxonomic descriptions, palaeoenvironments and palaeogeographical implications. Cretac. Res. 78, 206-220.

Casal, G.A., Allard, J.O., Foix, N., 2015. Análisis estratigráfico y paleontológico del Cretácico Superior en la Cuenca del Golfo San Jorge: nueva unidad litoestratigráfica para el Grupo Chubut. Rev. Asoc. Geol. Argent. 72, 77-95.

Chelotti, L.A., 1997. Evolución tectónica de la Cuenca del Golfo San Jorge en el Cretácico y Terciario; algunas observaciones desde la interpretación sísmica. Bol. Inf. Pet. 49, 62-82.

Clavijo, R., 1986. Estratigrafía del Cretácico Inferior en el sector Occidental de la Cuenca del Golfo San Jorge. Bol. Inf. Pet. 9, 15-32.

Codignotto, J., Nullo, F., Panza, J., Proserpio, C., 1978. Estratigrafía del Grupo Chubut entre Paso de Indios y Las Plumas, provincia del Chubut, Argentina. In: 7th Congreso Geológico Argentino, Actas, vol. 7. pp. 471-480 Neuquén.

Cortés, J., 1981. El sustrato pre-Cretácico del extremo nordeste de la provincia del Chubut. Rev. Asoc. Geol. Argent. 36, 217-235.

Colombo, F., 1994. Normal and reverse unroofing sequences in syntectonic conglomerates as evidence of progressive basinward deformation. Geology 22, 235-238.

Cortiñas, J.S., Arbe, H.A., 1981. El Cretácico continental de la región comprendida entre los cerros Guadal y Ferrarotti, Departamento Tehuelches, Provincia del Chubut. In: 8th Congreso Geológico Argentino, Actas, vol. 3. pp. 359-372 Buenos Aires.

Critelli, S., Ingersoll, R.V., 1995. Interpretation of neovolcanic vs. palaeovolcanic sand grains: an example from Miocene deep-marine sandstone of the Topanga Group (southern California). Sedimentology 42, 783-804.

Critelli, S., Le Pera, E., Ingersoll, R.V., 1997. The effects of source lithology, transport, deposition and sampling scale on the composition of southern California sand. Sedimentology 44, 653-671.

Cúneo, R., Ramezani, J., Scasso, R.A., Pol, D., Escapa, I., Zavattieri, A.M., Bowring, S. 2013. High-precision U-Pb geochronology and a new chronostratigraphy for the Cañadón Asfalto Basin, Chubut, Central Patagonia: implications for terrestrial faunal and floral evolution in Jurassic. Gondwana Res. 24, 1267-1275.

Datta, B., 2005. Provenance, tectonics and palaeoclimate of Proterozoic Chandarpur sandstones, Chhattisgarh Basin: a petrographic view. J. Earth Syst. Sci. 114, 227-245.

Di Capua, A., Groppelli, G., 2016. Application of actualistic models to unravel primary volcanic control on sedimentation (Taveyanne Sandstones, Oligocene Northalpine Foreland Basin). Sediment. Geol. 336, 147-160.

Dickinson, W.R., 1970. Interpreting detrital modes of graywacke and arkose. J. Sediment. Petrol. 40, 695-707.

Dickinson, W.R., Suczek, C.A., 1979. Plate tectonics and sandstone compositions. AAPG (Am. Assoc. Pet. Geol.) Bull. 63, 2164-2182.

Dickinson, W.R., Beard, L.S., Brakenridge, G.R., Erjavec, J.L., Ferguson, R.C., Inman, K.F., Knepp, R.A., Lindberg, F.A., Ryberg, P.T., 1983. Provenance of North American Phanerozoic sandstones in relation to tectonic setting. Geol. Soc. Am. Bull. 94, $222-235$.

Dorsey, R.J., 1988. Provenance evolution and unroofing history of a modern arc-continent collision: evidence from petrography of Plio-Pleistocene sandstones, eastern Taiwan. J. Sediment. Petrol. 58, 208-218.

Ferello, R., Tealdi, O.L., 1950. Descripción del perfil general del flanco oriental de la Sierra del Castillo. Unpublished Informe Interno YPF, Buenos Aires.

Figari, E.G., 2005. Evolución Tectónica de la Cuenca de Cañadón Asfalto. Tesis Doctoral 3896. Facultad de Ciencias Exactas y Naturales, Universidad Nacional de Buenos Aires. Biblioteca Digital FCEN-UBA, pp. 198.

Figari, E.G., García, D.G., 2018. Modelos analógicos superficie subsuelo para el Chubutiano Inferior de las cuencas de Cañadón Asfalto y del Golfo San Jorge, Argentina. In: X Congreso de Exploración y Desarrollo de Hidrocarburos, Sesiones Generales, pp. 669-688 (Mendoza).

Figari, E.G., Cid de la Paz, M.S., Laffitte, G., 1996. Neocomian half graben in the western San Jorge Basin, Argentina: petroleum systems, origin and tectonic inversion. Bull. Am. Assoc. Pet. Geol. 80, 1289-1290.

Figari, E.G., Strelkov, E., Laffitte, G., Cid De La Paz, M.S., Courtade, S.F., Celaya, J., Vottero, A., Lafourcade, P., Martínez, R., Villar, H., 1999. Los Sistemas Petroleros de la Cuenca del Golfo San Jorge: Síntesis Estructural, Estratigrafía y Geoquímica. In: Actas IV Congreso de Exploración y Desarrollo de Hidrocarburos, pp. 197-237 Mar del Plata.

Figari, E.G., Scasso, R.A., Cuneo, R., Escapa, I., 2015. Estratigrafía y evolución geológica de la Cuenca de Cañadón Asfalto, Provincia del Chubut, Argentina. Lat. Am. J. Sedimentol. Basin Anal. 22, 135-169.

Sedimentation in volcanic settings. In: In: Fisher, R.V., Smith, G.A. (Eds.), Society of Economic Paleontologists and Mineralogists, vol. 45. Special Publication, pp. 1-257.

Fitzgerald, M.G., Mitchum, R.M., Uliana, M.A., Biddle, K.T., 1990. Evolution of the san Jorge Basin, Argentina. AAPG (Am. Assoc. Pet. Geol.) Bull. 74 (6), 879-920.

Folguera, A., Iannizzotto, N., 2004. The Lagos La Plata and Fontana fold and thrust belt. Long lived orogenesis at the edge of western Patagonia. J. South Am. Earth Sci. 16, 541-566.

Folguera, A., Orts, D., Spagnuolo, M., Rojas Vera, E., Litvak, V., Sagripanti, L., Ramos, M.E., Ramos, V.A., 2011. A review of late Cretaceous to Quaternary palaeogeography of the southern Andes. Biol. J. Linn. Soc. 103, 250-268.

Folk, R.L., Andrews, P.B., Lewis, D.W., 1970. Detrital sedimentary rock classification and 
nomenclature for use in New Zealand. N. Z. J. Geol. Geophys. 13, 937-968.

Folk, R.L., 1980. Petrology of Sedimentary Rocks. Hamphills, Austin Texas, pp. 170.

Galeazzi, J.S., 1989. Análisis de facies y paleocorrientes de la Formación Matasiete en la sección Sur del Cañadón homónimo: Sierra de San Bernardo, Chubut, Argentina. Msc. Thesis. UBA, Buenos Aires, Argentina, pp. 182.

Garzanti, E., 2016. From static to dynamic provenance analysis - sedimentary petrology upgraded. Sediment. Geol. 336, 3-13.

Garzanti, E., Resentini, A., Andò, S., Vezzoli, G., Vermeesch, P., 2015. Physical controls on sand composition and relative durability of detrital minerals during long-distance littoral and eolian transport (coastal Namibia). Sedimentology 62, 971-996.

Genise, J.F., Melchor, R., Bellosi, E.S., Gonzalez, M.G., Krause, J.M., 2007. New insect pupation chambers (Pupichnia) from the upper Cretaceous of Patagonia, Argentina. Cretac. Res. 28, 545-559.

Giacosa, R., Márquez, M., Fernández, M.I., 2008. Estructura e interpretación tectónica del granito milonítico La Rueda: región central del Chubut. In: $17^{\circ}$ Congreso Geológico Argentino Actas, 835-836 (Jujuy).

Giampaoli, P., 2015. Caracterización de sistemas de fallas extensionales utilizando perfiles y mapas de desplazamiento: ejemplos del Cretácico de la cuenca del Golfo San Jorge. Rev. Asoc. Geol. Argent. 72, 111-123.

Gianni, G., Navarrete, C., Orts, D., Tobal, J., Folguera, A., Giménez, M., 2015a. Patagonian broken foreland and related synorogenic rifting: the origin of the Chubut Group Basin. Tectonophysics 649, 81-99.

Gianni, G.M., Navarrete, C.G., Folguera, A., 2015b. Synorogenic foreland rifts and transtensional basins: a review of Andean imprints on the evolution of the San Jorge Gulf, Salta Group and Taubaté basins. J. South Am. Earth Sci. 64, 288-306.

Gibling, M.R., 2006. Width and thickness of fluvial channel bodies and valley fills in the geological record: a literature compilation and classification. J. Sediment. Res. 76, 731-770.

Granot, R., Dyment, J., 2015. The Cretaceous opening of the south Atlantic Ocean. Earth Planet. Sci. Lett. 414, 156-163.

Hechem, J.J., Strelkov, E.E., 2002. Secuencia sedimentaria mesozoica del Golfo San Jorge. In: In: Haller, J.M. (Ed.), Geología y Recursos Naturales de Santa Cruz. Relatorio del $15^{\circ}$ Congreso Geológico Argentino, vol. 1. pp. 129-147 (Buenos Aires).

Hechem, J.J., Figari, E.G., Musacchio, E.A., 1987. Hallazgo de la Formación Pozo D-129. Petrotecnia 18, 13-15.

Hechem, J.J., Homovc, J.F., Figari, E.G., 1990. Estratigrafía del Chubutiano (Cretácico) en la Sierra de San Bernardo, cuenca del Golfo San Jorge, Argentina. In: 11th Congreso Geológico Argentino, Actas, vol. 3. pp. 173-176 San Juan.

Homovc, J.F., Lucero, M., 2002. Cuenca del Golfo San Jorge: marco geológico y reseña histórica de la actividad petrolera. In: Schiuma, M., Hinterwimmer, G., Vergani, G. (Eds.), Rocas Reservorio de las Cuencas Productivas de la Argentina. Instituto Argentino del Petróleo y del Gas, Buenos Aires, pp. 119-134.

Homovc, J.F., Conforto, G.A., Lafourcade, P.A., Chelotti, L.A., 1995. Fold Belt in the San Jorge basin, Argentine: an example of tectonic inversion. In: In: Buchanan, J.G., Buchanan, P.G. (Eds.), Basin Inversion, vol. 88. Geological Society of London, Special Publication, pp. 235-248.

Ingersoll, R.V., Cavazza, W., 1991. Reconstruction of Oligo-Miocene volcaniclastic dispersal patterns in north-central New Mexico using sandstone petrofacies. In: In: Fisher, R.V., Smith, G.A. (Eds.), Sedimentation in Volcanic Settings, vol. 45. SEPM, Special Publication, Tulsa, pp. 227-236.

Jalfin, G., Bellosi, E., Sanagua, J., Villar, H., 1999. Procesos múltiples de migración, alteración y mezcla en petróleos de la Cuenca del Golfo San Jorge: una evaluación geoquímica integrada. In: $4^{\circ}$ Congreso de Exploración y Desarrollo de Hidrocarburos, pp. 445-465 (Buenos Aires).

Kataoka, K.S., Nakajo, T., 2002. Volcaniclastic resedimentation in distal fluvial basins induced by large-volume explosive volcanism: the Edisutoge-Fukuda tephra, PlioPleistocene boundary, central Japan. Sedimentology 49, 319-334.

Kataoka, K.S., Manville, V., Nakajo, T., Urabe, A., 2009. Impacts of explosive volcanism on distal alluvial sedimentation: examples from the Pliocene-Holocene volcaniclastic successions of Japan. Sediment. Geol. 220, 306-317.

Laffitte, G.A., Villar, H.J., 1982. Poder reflector de la vitrinita y madurez térmica: Aplicación en el sector NO de la Cuenca del Golfo San Jorge. In: $1^{\circ}$ Congreso de Hidrocarburos, Petróleo y Gas, Trabajos Técnicos Exploración, pp. 171-182 (Buenos Aires).

Lesta, P., 1968. Estratigrafía de la Cuenca del Golfo San Jorge. In: $3^{\circ}$ Jornadas Geológicas Argentinas, Actas, vol. 1. pp. 251-289.

Lesta, P., Ferello, R., 1972. Chubut extraandino. In: Leanza, A. (Ed.), Academia Nacional de Ciencias. Geología Regional Argentina, Córdoba, pp. 601-654.

Limarino, C.O., Giordano, S.R., 2016. Unraveling multiple provenance areas using sandstone petrofacies and geochemistry: an example in the southern flank of the Golfo San Jorge Basin (Patagonia, Argentina). J. South Am. Earth Sci. 66, 208-231.

Limarino, C.O., Giordano, S.R., Rodriguez Albertani, R., 2017. Diagenetic model of the Bajo Barreal Formation (Cretaceous) in the southwestern flank of the Golfo san Jorge Basin (Patagonia, Argentina). Mar. Pet. Geol. 88, 907-931.

Mack, G.H., Leeder, M.R., 1998. Channel shifting of the Rio Grande, southern Rio Grande rift: implications for alluvial stratigraphic models. Sediment. Geol. 117, 207-219.

Manville, V., Nemeth, K., Kano, K., 2009. Source to sink: a review of three decades of progress in the understanding of volcaniclastic processes, deposits, and hazards. Sediment. Geol. 220, 136-161.

Mathisen, M.E., Vondra, C.F., 1983. The fluvial and pyroclastic deposits of the Cagayan Basin, northern Luzon, Philippines - an example of nonmarine volcaniclastic sedimentation in an interarc basin. Sedimentology 30, 369-392.

McBride, E.F., 1985. Diagenetic processes that affect provenance determinations in sandstones. In: In: Zuffa, G.G. (Ed.), Provenance of Arenites. Reidel, vol. 148. NATO ASI Series, Dordrecht, pp. 95-113.

McBride, E.F., Picard, M.D., 1987. Downstream changes in sand composition, roundness, and gravel size in a short-headed, high-gradient stream, northwestern Italy. J. Sediment. Petrol. 57, 1018-1026.

Miall, A.D., 2014. Fluvial Depositional Systems. Springer, Switzerland, pp. 316.

Nagel, S., Castelltort, S., Garzanti, E., Lin, A.T., Willett, S.D., Mouthereau, F., Limonta, M., Adatte, T., 2014. Provenance evolution during arc-continent collision: sedimentary petrography of Miocene to Pleistocene sediments in the western foreland basin of Taiwan. J. Sediment. Res. 84, 513-528.

Nakayama, C., 1973. Sedimentitas prebajocianas en el extremo austral de la sierra de Taquetrén, Chubut, Argentina. In: 5th Congreso Geológico Argentino, pp. 269-278 (Buenos Aires).

Navarrete, C., Gianni, G., Echaurren, A., Lince Kingler, F., Folguera, A., 2016. Episodic Jurassic to lower Cretaceous intraplate compression in central Patagonia during Gondwana breakup. J. Geodyn. 102, 185-201.

Ori, G.G., Diachille, G., Komatsu, G., Marinangeli, L., Rossi, A.P., 2007. River morphologies and palaeodrainages of western Africa (Sahara and Sahel) during humid climatic conditions. In: In: Nichols, G., Williams, E., Paola, C. (Eds.), Sedimentary Processes, Environments and Basins, vol. 38. IAS Special Publication, pp. 519-533.

Paredes, J.M., Hudecek, R., Foix, N., Rodriguez, J.F., Nillni, A., 2003. Análisis paleoambiental de la Formación Matasiete (Aptiano) en su área tipo, noroeste de la Cuenca del Golfo San Jorge, Argentina. Asoc. Argent. Sedimentol. Rev, 10, 82-101.

Paredes, J.M., Azpiroz, G., Foix, N., 2006. Tertiary tectonics and sedimentation in the cerro Piedra oil field Golfo san Jorge Basin, Argentina. In: IV Latin American Congress of Sedimentology, Abstract. San Carlos de Bariloche, Argentina, pp. 163.

Paredes, J.M., Foix, N., Colombo, F., Nillni, A., Allard, J.O., Marquillas, R., 2007. Volcanic and climatic control on fluvial style in a high energy system: the Lower Cretaceous Matasiete Formation, Golfo San Jorge basin, Argentina. Sediment. Geol 202, 96-123.

Paredes, J.M., Plazibat, S., Crovetto, C., Stein, J., Cayo, E., Schiuma, A., 2013. Fault kinematics and depocenter evolution of oil-bearing, continental successions of Mina del Carmen Formation (Albian) in the Golfo San Jorge basin, Argentina. J. South Am. Earth Sci. 46, 63-79.

Paredes, J.M., Allard, J.O., Foix, N., Alvarez, B., Olazábal, S.X., 2014. Sedimentología y perfiles de rayos gamma de la Formación Pozo D-129 en la Sierra de San Bernardo, Chubut. In: 9th Congreso de Exploración y Desarrollo de Hidrocarburos, Trabajos Técnicos, pp. 455-479 (Mendoza).

Paredes, J.M., Foix, N., Allard, J.O., Colombo, F., Tunik, M.A., 2015. Alluvial architecture of reworked pyroclastic deposits in peri-volcanic basins: Castillo formation (albian) of the Golfo san Jorge Basin, Argentina. Rev. Asoc. Geol. Argent. 72, 42-62.

Paredes, J.M., Foix, N., Allard, J.O., 2016. Sedimentology and alluvial architecture of the Bajo Barreal Formation (upper Cretaceous) in the Golfo san Jorge Basin: outcrop analogues of the richest oil-bearing fluvial succession in Argentina. Mar. Pet. Geol. 72, 317-335.

Paredes, J.M., Aguiar, M., Ansa, A., Giordano, S.R., Ledesma, M., Tejada, S., 2018. Inherited discontinuities and fault kinematics of a multiphase, non-colinear extensional setting: subsurface observations from the south flank of the Golfo san Jorge Basin, Patagonia. J. South Am. Earth Sci. 81, 87-107.

Paredes, J.M., Giordano, S.R., Valle, M.N., Olazábal, S.X., Allard, J.O., Foix, N., Tunik, M.A., 2020. Climatic control on stacking density of fluvial successions: upper Cretaceous Bajo Barreal Formation of the Golfo san Jorge Basin, Patagonia. Mar. Pet. Geol. 113, 104116.

Perez Loinaze, V.S., Césari, S.N., Giordano, S.R., Stach, N.H., Ansa, A., 2019. Palynological analysis of a lower Cretaceous subsurface succession from the South flank of the Golfo san Jorge Basin, Argentina. Cretac. Res. 97, 94-106.

Proserpio, C.A., 1987. Descripción geológica de la Hoja 44e, Valle General Racedo, Pcia. del Chubut. In: Dirección Nacional de Minería y Geología, Boletín, vol. 201. pp. 108 (Buenos Aires).

Powers, M., 1953. A new roundness scale for sedimentary particles. J. Sediment. Petrol. 23, 117-119.

Robbiano, J.A., 1971. Contribución al conocimiento estratigráfico de la sierra del cerro negro, Pampa de Agnia, provincia del Chubut, república Argentina. Rev. Asoc. Geol. Arg. 26 (1), 41-56.

Rodriguez, J.F.R., Bitschene, P., 1994. Composición y origen de sedimentos piroclásticos silíceos del Cretácico superior (Fm. Bajo Barreal) en la Patagonia Central, Argentina. Zlb. Geol. Palaont. T., H 7/8, 753-765 (Stuttgart).

Rodriguez, J.F., Littke, R., 2001. Petroleum generation and accumulation in the Golfo San Jorge Basin, Argentina: a basin modeling study. Mar. Pet. Geol. 18, 995-1028.

Romans, B.W., Fildani, A., Graham, S.A., Hubbard, S.M., Covault, J.A., 2010. Importance of predecessor basin history on the sedimentary fill of a retroarc foreland basin: provenance analysis of the Cretaceous Magallanes basin, Chile (50-52 S). Basin Res. $22,640-658$.

Sciutto, J.C., 1981. Geología del Codo del Río Senguerr, Chubut, Argentina. In: $8^{\circ}$ Congreso Geológico Argentino, Actas, vol. 3. pp. 203-219 San Luis.

Secretaría de Energía, 2017. Informe estadístico anual 2017 del sector energético. Ministerio de Energía y Minería. Secretaría de Planeamiento Energético Estratégico, pp. 42.

Silva Nieto, D.G., Cabaleri, N.G., Salani, F., González Díaz, E., Coluccia, A., 2002. Hoja Geológica 4368-27 Cerro Condor, provincia del Chubut, vol. 328. Instituto de Geología y Recursos Minerales, Servicio Geológico Minero Argentino, Boletín, Buenos Aires, pp. 68.

Silva Nieto, D.G., 2005. Hoja Geológica 4369-III, Paso de Indios, provincia del Chubut, vol. 265. Instituto Geología y Recursos Minerales, Servicio Geológico Minero Argentino, Boletín, pp. 72.

Smith, G.A., 1991. Facies sequences and geometries in continental volcaniclastic sediments. In: In: Fisher, R.V., Smith, G.A. (Eds.), Sedimentation in Volcanic Settings, vol. 45. Special Publication, pp. 109-121 Society of Economic Paleontologists and Mineralogists.

Sruoga, P., Busteros, A., Giacosa, R., Kleiman, L., Japas, S., Maloberti, A., Martínez, H., 
2008. Análisis litofacial y estructural del Complejo Bahía Laura en el área El Dorado Monserrat, pcia. de Santa Cruz, Argentina. Rev. Asoc. Geol. Argent. 63 (4), 653-664.

Stipanicic, P., Rodrigo, F., Baulíes, O., Martínez, C., 1968. Las formaciones presenonianas en el denominado Macizo Nordpatagónico y regiones adyacentes. Rev. Asoc. Geol. Argent. 23, 67-98.

Sylwan, C.A., 2001. Geology of the Golfo san Jorge Basin, Argentina. J. Iber. Geol. 27, 123-157.

Sylwan, C., Droeven, C., Iñigo, J., Mussel, F., Padva, D., 2011. Cuenca del Golfo San Jorge. In: VIII Congreso de Exploración y Desarrollo de Hidrocarburos, Simposio Cuencas Argentinas, pp. 139-183 (Mar del Plata).

Taylor, J.M., 1950. Pore-space reduction in sandstones. AAPG (Am. Assoc. Pet. Geol.) Bull. 34, 701-716.

Tooth, S., 2000. Process, form and change in dryland rivers: a review of recent research. Earth Sci. Rev. 51, 67-107.

Tunik, M.A., Vietto, M.E., Sciutto, J.C., Estrada, E., 2004. Procedencia de areniscas del Grupo Chubut en el área central de la Sierra de San Bernardo. Informe Preliminar. Rev. Asoc. Geol. Argent. 59, 601-606.

Tunik, M.A., Paredes, J.M., Fernández, M.I., Foix, N., Allard, J.O., 2015. Análisis petrográfico de areniscas de la Formación Castillo (Albiano) en la Faja Plegada de San Bernardo, cuenca Golfo San Jorge, Argentina. Rev. Asoc. Geol. Argent. 72, 63-80.

Ulmer-Scholle, D.S., Scholle, P.A., Schieber, J., Raine, R.J., 2015. A color guide to the petrography of sandstones, siltstones, shales and associated rocks. AAPG (Am. Assoc. Pet. Geol.) Mem. 109, 509.

Umazano, A.M., Bellosi, E., Visconti, G., Melchor, R.N., 2008. Mechanisms of aggradation in fluvial systems influenced by explosive volcanism: an example from the late Cretaceous Bajo Barreal Formation, san Jorge Basin, Argentina. Sediment. Geol 203, 213-228.

Umazano, A.M., Bellosi, E.S., Visconti, G., Jalfin, G.A., Melchor, R.N., 2009. Sedimentary record of a late Cretaceous volcanic arc in central Patagonia: petrography, geochemistry and provenance of fluvial volcaniclastic deposits of the Bajo Barreal Formation, san Jorge Basin, Argentina. Cretac. Res. 30, 749-766.

Umazano, A.M., Bellosi, E.S., Visconti, G., Melchor, R.N., 2012. Detecting allocyclic signals in volcaniclastic fluvial successions: facies, architecture and stacking pattern from the Cretaceous of central Patagonia, Argentina. J. South Am. Earth Sci. 40, 94-115.

Urien, C.M., Zambrano, J.J., Yrigoyen, M.R., 1995. Petroleum basins of southern south America: an overview. In: In: Tankard, A.J., Suárez-Soruco, R., Welsink, H. (Eds.), Petroleum Basins of South America, vol. 62. AAPG Memoir, Tulsa, pp. 63-77.

Vallati, P., 1996. In: Palynology of the D-129 Formation in the San Jorge Gulf Basin, Lower Cretaceous, Patagonia, Argentina. En: Congreso Brasileiro De Geologia, vol. 39. Anais, Salvador, pp. 423-426 7.

Vallati, P., 2013. A mid-Cretaceous palynoflora with Tucanopollis crissopolensis from D129 formation, San Jorge Gulf basin, Argentina. Rev. Bras. Palaontol. 16, 237-244.

Vallati, P., Casal, G., Foix, N., Allard, J.O., De Sosa Tomas, A., Calo, M., 2016. First report of a Maastrichtian palynoflora from the Golfo san Jorge Basin, central Patagonia, Argentina. Ameghiniana 53, 495-505.

Welton, J.E., 1984. SEM Petrology Atlas. Am. Ass. Pet. Geol, Tulsa, Oklahoma, USA, pp. 237.

Zaffarana, C., Gallastegui, G., Lagorio, S., Poma, S., Busteros, A., Serra Varela, S., Orts, D., Silva Nieto, D., Giacosa, R., Ruiz González, V., Puigdomenech, C., Boltshauser, B., Somoza, R., 2018. Geochemical signature and reservoir conditions of early Jurassic calc-alkaline volcanic rocks from Lonco Trapial Formation, central Patagonia. J. South Am. Earth Sci. 88, 415-445.

Zimmermann, U., Bahlburg, H., 2003. Provenance analysis and tectonic setting of the Ordovician clastic deposits in the southern Puna Basin, NW Argentina. Sedimentology 50, 1079-1104.

Zuffa, G.G., 1985. Optical analyses of arenites: influence of methodology on compositional results. In: Provenance of Arenites. Springer, Netherlands, pp. 165-189.

Zuffa, G.G., Cibin, U., Di Giulio, A., 1995. Arenite petrography in sequence stratigraphy. J. Geol. 103, 451-459.

Zuffa, G.G., Normark, W.R., Serra, F., Brunner, C.A., 2000. Turbidite Megabeds in an oceanic rift valley recording Jökulhlaups of late Pleistocene glacial lakes of the western United States. J. Geol. 108, 253-274. 